\author{
Universidade de São Paulo \\ Faculdade de Filosofia, Letras e Ciências Humanas \\ Departamento de Filosofia \\ Programa de Pós-Graduação em Filosofia
}

Gabriela Doll Ghelere

\title{
A liberdade individual para Benjamin Constant
}


Gabriela Doll Ghelere

\section{A liberdade individual para Benjamin Constant}

Dissertação apresentada ao Departamento de Filosofia da Faculdade de Filosofia, Letras e Ciência Humanas da Universidade de São Paulo, sob orientação do Prof. Dr. Renato Janine Ribeiro, como exigência parcial para a obtenção do título de mestra em Filosofia 
À lembrança de Gerson Galvão Ghelere, meu pai, "porque a ausência, essa ausência assimilada, ninguém a rouba mais de mim" .

(Drummond) 
Agradeço ao professor Renato Janine Ribeiro, pela orientação e interlocução, ao professor Modesto Florenzano, pela leitura e indicações preciosas no exame de qualificação, e à professora Maria das Graças de Souza pela leitura e advertências sábias no exame de qualificação. Agradeço aos amigos Rodrigo Brandão, Marcos Sacrini, Sylvia e Leandro Cardim, Carolina Noto e Pedro Falleiros, Guilherme Braun, pelos incentivos calorosos ao longo desses anos, ao Ronaldo Manzi, pela paciência técnica, ao Daniel Bonomo, pela dedicação ao texto, ao Anderson Gonçalves da Silva, leitor atencioso e exigente, à Aida Schwab, interlocutora afetiva. Agradeço especialmente à Laurici Doll Ghelere, minha mãe, pelo amparo e por compartilhar as angústias, Ana Maria e Santiago Portas, pelo carinho, e ao Federico Esquerro, companheiro fiel, parceiro dedicado, meu grande amor. 


\section{Resumo:}

GHELERE, Gabriela Doll. A liberdade individual para Benjamin Constant. 2008. 94 f. Dissertação (Mestrado) - Faculdade de Filosofia Letras e Ciências Humanas. Departamento de Filosofia, Universidade de São Paulo, São Paulo, 2008.

Aqui investigamos o conceito de liberdade individual na teoria de Benjamin Constant. Partimos da conferência intitulada De la Liberté des Anciens comparée à celle des Modernes, e verificamos que o contraste entre a liberdade individual dos modernos e a liberdade política dos antigos não exclui completamente da vida dos modernos a necessidade de participação política. Assim, recorremos, no segundo capítulo, a outros textos de Benjamin Constant, sobretudo aos Principes de Politique, para examinar os pressupostos da sua teoria política: o problema da soberania do povo, a construção da noção de representatividade política e a dupla autoridade da natureza e da história que fundamentam respectivamente as noções de liberdade e igualdade. No terceiro capítulo buscamos os desdobramentos do conceito de liberdade moderna, isto é, o que caracteriza o liberalismo de Constant e o diagnóstico que ele aponta sobre o indivíduo moderno. Por conseguinte, sustentamos que a peculiaridade do liberalismo de Constant é articular a liberdade civil do indivíduo e a liberdade política de participação. Mas, no grande romance seu que é Adolfo, Constant relaciona indivíduo e sociedade de uma maneira que tanto recorda sua defesa da liberdade dos modernos quanto mostra os limites desta. Nossa conclusão é portanto uma pergunta, que sustentamos estar presente no próprio Constant: qual o valor, quais as perspectivas dessa liberdade moderna?

Palavras-chave: liberdade, liberalismo, indivíduo, política, moderno. 


\begin{abstract}
:
GHELERE, Gabriela Doll. Individual liberty for Benjamin Constant. 2008. 94 f. Master's Degree Dissertation - Faculdade de Filosofia Letras e Ciências Humanas. Departamento de Filosofia, Universidade de São Paulo, São Paulo, 2008.
\end{abstract}

Here we inquire the concept of individual liberty in Benjamin Constant's theory. We started with the conference entitled De la Liberté des Anciens comparée à celle des Modernes, and verified that the contrast between individual liberty for the moderns and political liberty for the ancients doesn't prevent the moderns from having the necessity of political participation. Therefore, in the second chapter, other texts by Benjamin Constant are studied, mainly Principes de Politique, in order to scrutinize the background of his theory: the issue of the people's sovereign, the creation of the idea of political representativeness, and the double authority of the nature and the history that are base for the concepts of liberty and equality, respectively. In the third chapter we analyze the implications of the concept of modern liberty, that is, what characterizes Constant's liberalism and how he diagnosis the modern individual. By doing so, we affirm that what is peculiar about Constant's liberalism is how he connects the civil liberty of the individual to the political liberty of participation. However, in his great novel Adolfo, Constant links individual and society in such a way that it recalls his defense of liberty in the moderns but also shows the limits of that. Our conclusion is, therefore, a question, that we affirm to be present in Constant: what value, what perspectives of this modern liberty?

Keywords: Liberty, liberalism, individual, politics, modern 


\section{Índice}

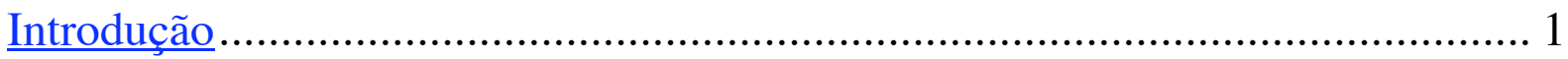

Capítulo 1: Liberdade antiga e moderna ......................................................... 10

I - A querela

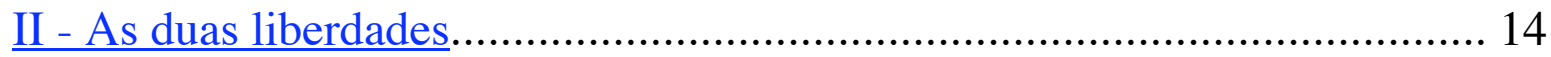

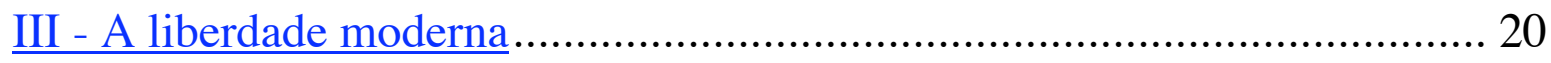

Capítulo 2: os pressupostos do conceito de liberdade ...................................... 29

I - O problema da soberania do povo....................................................... 29

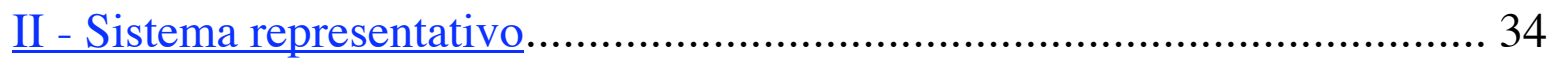

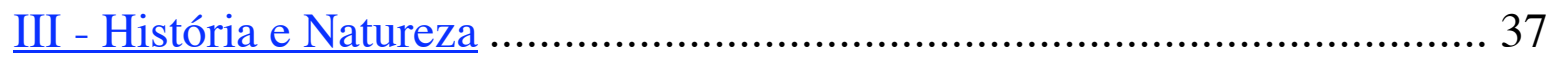

Capítulo 3: desdobramentos da liberdade moderna - o sistema político e o

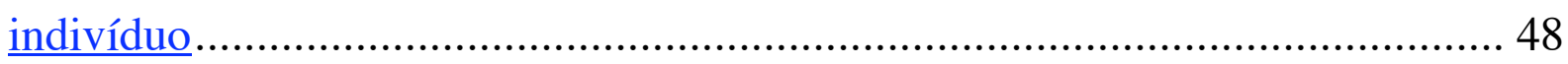

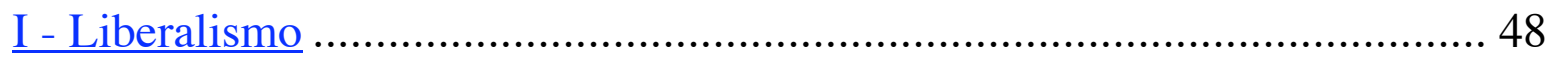

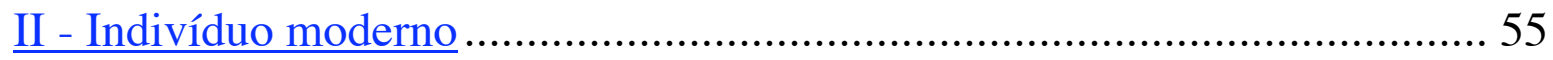

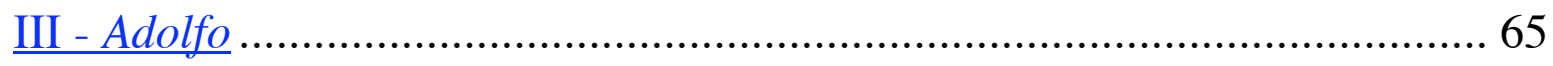

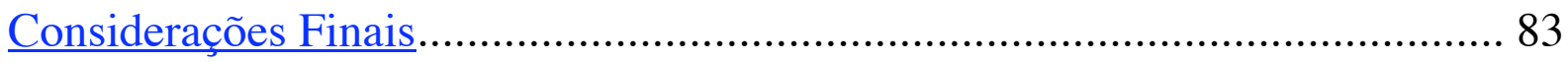

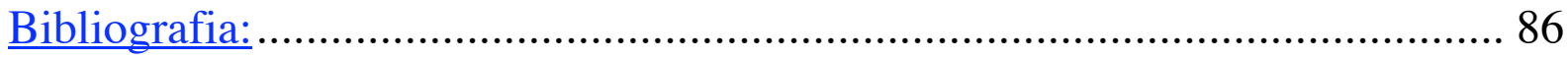




\section{Introdução}

"A liberdade é o poder que o homem tem de fazer tudo o que não prejudique os direitos dos outros." Começamos esta investigação com um conceito, a liberdade que se define pela negação do outro, tal como aparece na Declaração dos Direitos do Homem e do Cidadão ${ }^{l}$. A fórmula usada é a seguinte: "Ser livre reside em não ser impedido de atuar segundo os objetivos que se escolheram e não sofrer constrangimentos". Ou como aparece no Artigo 4: "A liberdade reside em poder fazer tudo o que não prejudique a outrem: assim o exercício dos direitos naturais de cada homem só tem limites que garantem aos outros membros da sociedade o gozo dos mesmos direitos. Tais limites só podem ser determinados pela Lei" ${ }^{2}$. Embora com diferenças - a segunda formulação tenta evitar o arbítrio do indivíduo -, há em comum nas definições um indivíduo que não precisa mais lutar por si só contra o indesejado, ou melhor, contra os constrangimentos que os outros possam lhe impor; a função de proteger o indivíduo é do direito. Começamos a falar a partir de 1789, mas ainda estamos no registro do contratualismo do início do XVII.

Alguns filósofos como Hobbes e Montesquieu, ao pensarem esse conceito, fundaram o liberalismo; obra que é, se não o início, um marco decisivo dos últimos anos do século XVIII na história da filosofia política. Encontramos igualmente filósofos como Marx, que, ao se formarem críticos do liberalismo e da teoria política como um todo, viram-se na difícil tarefa de também questionar o conceito. Fomos, assim, buscar a liberdade do indivíduo lá onde ela é defendida em uma de suas primeiras vezes ${ }^{3}$, e vimos que é chamada de liberdade individual. Há tanto um traço moderno que compõe a idéia antiga de liberdade como há uma perspectiva de indivíduo nascente nos conturbados anos da Revolução Francesa. Assim

\footnotetext{
${ }^{1}$ O primeiro texto da Declaração data de 26 de agosto de 1789 e, embora tenha sido substituído duas vezes (na Constituição de 1793, e depois por outro texto dos direitos e deveres na Constituição de 1795), prevaleceu historicamente o original, ainda que um projeto inacabado pois, no dia seguinte, foi interrompido pela urgência da Constituição.

${ }^{2}$ Artigo proposto por Lameth, inspirado por Sieyès, de acordo com Marcel Gauchet no verbete "Direitos do Homem", do Dicionário Crítico da Revolução Francesa.

${ }^{3}$ Pierre Manent delineia a História intelectual do liberalismo: dez lições , abordando a construção histórica do conceito de liberdade individual, de Hobbes a Tocqueville. Manent traça uma primeira fase do liberalismo, com Hobbes, Locke, Montesquieu, e depois o liberalismo pós-revolucionário, com Constant, Guizot e Tocqueville.
} 
também entendemos que há um vínculo ${ }^{4}$ entre vida e teoria políticas na época moderna, especialmente no período em que Benjamin Constant escreve sua contribuição e participa ${ }^{5}$ ativamente da vida política ${ }^{6}$.

Entretanto, nos primeiros momentos da Revolução Francesa, Constant não está em Paris, mas na Inglaterra e Holanda, resolvendo problemas financeiros do pai e estudando na atmosfera das Luzes. De 1783 a 1785 ele vive em Edimburgo, onde recebe forte influência das Luzes Escocesas. De 1788 a 1794, vive em Brunswick, onde conhece Mme. de Staël freqüenta o Grupo de Coppet e viaja freqüentemente à Suíça e Holanda. Assiste à Revolução, neste período, à distância. Só desembarca em Paris, junto com Mme de Staël, em maio de $1795^{8}$, quando a Convenção Termidoriana chegava ao fim e se preparava uma nova Constituição Republicana, que viria a inaugurar o sistema do Diretório. Oscilante em algum momento, Constant chegou a esboçar uma defesa do jacobinismo, mas logo compreendeu, sobretudo pelas relações com sua interlocutora, que o elogio à Revolução não precisa carregar junto dele o Terror. É preciso salvar a Revolução9 pelo que ela tem de melhor: a República, o sistema eletivo. Com esse tom moderado, o jovem Constant, aos 28 anos, decide-se pelo engajamento político. Moderação e entusiasmo, necessidade de estabilidade em meio à

\footnotetext{
${ }^{4}$ Cf Pierre Manent que argumenta essa idéia na comparação com os antigos. A Grécia, afirma ele, foi o berço da filosofia política, e foi a partir da experiência política que Platão e Aristóteles construíram suas teorias, ou seja, as interpretações vieram depois da prática. Já no caso dos modernos, Manent fica "tentado" a afirmar que a teoria liberal veio antes de sua prática - a experiência da Revolução Francesa - com Hobbes, e foi desenvolvida durante esse processo, com Constant e Guizot, e aperfeiçoada por Tocqueville. Vale ressaltar que Constant é, dentre esses autores estudados por Manent, o que mais se aproxima da experiência prática da Revolução.

${ }^{5}$ Benjamin Constant nasceu em 1767 em Lausanne, na Suiça. Era descendente das famílias francesas protestantes que haviam se refugiado na Suiça por causa das perseguições religiosas. Isso fez com que sua família lutasse para recuperar sua cidadania francesa. A preocupação de Constant era que não lhe concedessem a possibilidade de participar da vida política na condição de estrangeiro. Costumava dizer que era mais francês do que muitos franceses.

${ }^{6}$ EtienneHofmann sustenta que nos primeiros anos da Revolução Benjamin Constant não se interessa pelos acontecimentos na França, diferente de Gustave Rudler, que já encontra um posicionamento político do autor desde o início. Preferimos contornar o problema levando em consideração que seus escritos políticos começam em 1796. Notamos que, se Constant não acompanhou com interesse os primeiros acontecimentos revolucionários, foi logo em seguida que tomou conhecimento e passou a vivenciá-los, tomando posição política.

${ }^{7}$ Embora a relação entre Benjamin Constant e Mme. de Staël tenha sido muito intensa, tanto pessoalmente, pois foram amantes e tiveram um filho, quanto politicamente (até escreveram alguns textos juntos), não trataremos nessa dissertação dessa relação. Há aproximações e distanciamentos entre as duas teorias, que poderiam ser outro objeto de estudo. Tampouco entramos nas questões pertinentes à influência que ela exerceu sobre ele; alguns comentadores entendem que muito e outros que bem pouco.

${ }^{8}$ Precisamente no 6 Prairial do ano III, dia 25 de maio.

9 “Quando o acordo entre as instituições e as idéias se vê destruído, as revoluções se tornam inevitáveis. Elas tendem a estabelecer esse acordo. Não é sempre o objetivo dos revolucionários, mas é sempre a tendência das revoluções", escreve Constant em seu texto contra a Reação.
} 
desordem e muitas dúvidas. Defendeu o governo diretorial, foi chamado de $\operatorname{arrivista}^{10}$, "durante todo o período do Diretório, e mesmo depois, nós veremos Constant tentar, em vão, conciliar a intenção com a realização, a teoria com a prática e o pensamento com a experiência" (HOFMANN, 1980, p. 100, grifos nossos). Há controvérsias. Seus adversários o chamaram de "Constant, l'inconstant". Mas ninguém discorda - e isso nos interessa - que teoria e prática, escritos filosóficos e cargos políticos foram feitos e ocupados com muita dedicação e intensidade, num momento particularmente agitado da história francesa. Ele posiciona-se ao lado dos termidorianos com Mme. de Staël em setembro de 1795, no momento da elaboração de uma nova Constituição, inclinada a terminar a Revolução, protegendo-a de todo risco de retorno ao Terror. O momento político era muito delicado, pois estavam por elaborar a Constituição do ano III e o desafio que se impôs ao jovem Constant foi o de equacionar um sistema que rompesse, sem retorno, com o Terror, mas que ao mesmo tempo garantisse a continuidade da proposta inicial da Revolução. Em que termos definir uma república constitucional? Benjamin Constant simpatizava, assim, com a proposta de um sistema representativo que limitasse a soberania do povo, que protegesse as liberdades individuais contra o perigo de sua anulação ou inviabilidade pelo discurso da vontade geral. Queria a estabilidade em tempos de tumulto, isto é, a república, neste momento, poderia garantir a tranqüilidade e a paz. Volta-se contra os monarquistas moderados na sua primeira brochura política De la force du governement actuel de la France et de la nécessité de s'y rallier, publicada em 1796, pois, oportunamente, acredita que a monarquia não está de acordo com os princípios reconhecidos neste momento como verdadeiros. No ano seguinte publica Des réactions politiques e Des effets de la Terreur. Entra definitivamente no debate da Revolução contra os reacionários. Constant está profundamente envolvido como um escritor político e muito bem informado sobre a situação política. Freqüenta os meios que lhe interessam: o Diretório, o círculo constitucional, as casas de alguns deputados, o grupo de Mme. de Staël e os salões. Nesse momento, o conceito de liberdade ainda está de alguma forma amarrado ao sistema político: a república lhe parece a forma possível de garantir, na atualidade, a liberdade; a monarquia, com a possibilidade de um golpe de Estado, e o Terror,

\footnotetext{
10 "Ele é positivamente um oportunista", afirma Hofmann, pois leva em consideração a adequação entre suas idéias e as circunstâncias. (1980, p.123.)
} 
por si só, são inimigos da liberdade. Entretanto, começa um período mais controverso na vida política de Constant e dos republicanos. Violações das constituições, golpes de Estado, a república ameaçada. Benjamin Constant critica tanto o sistema hereditário e luta fervorosamente contra o poder arbitrário quanto defende a igualdade jurídica e a liberdade. Faz sua defesa da propriedade privada e nega os direitos políticos aos não-proprietários, em nome da independência ou autonomia. É acusado, pelo grupo republicano reunido no jornal Ami des lois, de monarquista e de estrangeiro. Chega o 18 de Brumário ${ }^{11}$, quando a nomeação dos três cônsules - Bonaparte, Siéyès e Ducos - faz com que Constant envie uma carta ao amigo Siéyès, denunciando as ambições de Bonaparte. Aos poucos observamos uma mudança na sua posição política: não se trata mais de defender a república, é preciso defender a liberdade contra o poder autoritário. Aproxima-se, desse modo, da liberdade da Declaração dos direitos do homem e do cidadão: a liberdade é um escudo protetor contra o poder arbitrário.

Em dezembro de 1799, devido à amizade com Siéyès e por recomendação de Staël, Constant é nomeado membro do Tribunato, uma espécie de câmara consultiva composta por cem membros. O Tribunato não tem uma função deliberativa, discute sem votar as leis que o Conselho de Estado propôs e que o Corpo Legislativo depois irá votar, sem debater. Benjamin Constant vive intensamente este cargo político que também significa, indiretamente, que a França, por fim, o considera um cidadão francês. Agora, em 1800, o perigo não é mais o Terror, é a ditadura. "A situação é inversa para Constant: sob o Diretório, tratara de defender o governo, em nome dos princípios e contra certas opiniões; sob o Consulado e o Império, é preciso antes defender os princípios, contra o governo e apesar da opinião" (HOFMANN, 1980, p. 195). Nos seus discursos como tribuno, Constant edifica uma oposição aos abusos da administração, defende os indivíduos e as minorias oprimidas, enfim, fomenta uma barreira ao poder, reivindicando a constitucionalidade governamental. O cargo de tribuno de Constant termina bruscamente no dia 17 de janeiro de 1802, assim como os de outros membros

\footnotetext{
${ }^{11}$ Constant refere-se ao 18 de Brumário diversas vezes. Em 22 de agosto de 1799 inicia-se um processo constitucional que implanta o Diretório. Em 9 de novembro, o 18 de Brumário, coloca-se uma nova constituição, cuja organização prevê o Consulado como poder executivo. No primeiro momento, o Consulado é composto pelos três cônsules citados, no ano seguinte o poder executivo é confiado somente a Bonaparte, e Constant o considera um déspota, pois intervém tanto no legislativo quanto no judiciário e nomeia os cargos mais importantes.
} 
considerados intelectuais oposicionistas. Constant torna-se persona non grata em Paris. Em 1802, Napoleão será nomeado cônsul perpétuo por plebiscito, com o apoio da burguesia. Em maio Constant vai a Coppet, e acompanha Staël - exilada por Bonaparte - em algumas viagens pela Suíça e Alemanha. Em Weimar encontra a elite de pensadores alemães: Goethe, Schiller, Wieland, Müller, entre outros.

Durante suas longas discussões com estes interlocutores, escreve dois romances e retoma seus escritos sobre religião. Nos anos seguintes (até 1806) escreve, mesmo sem publicá-los, os Fragments d'un ouvrage abandonnée sur la possibilité d'une constituition républicaine dans un grand pays e os Principes de politique applicables à tous les governements. Busca, com esses textos, um bom funcionamento do sistema eletivo e se inscreve com mais solidez no movimento liberal, ou seja, começa a pensar que a liberdade é um princípio que deve estar dissociado da forma de governo, seja monarquista, seja republicana. Em 1806, no auge do poder imperial, Benjamin Constant renuncia a defender uma constituição republicana.

De 1811 a 1813 Benjamin Constant se enclausura na biblioteca da Universidade de Göttingen. Em 1813 Napoleão é vencido em Leipzig e as tropas francesas evacuam da Alemanha. Primeira queda de Napoleão. Em janeiro de 1814, com Napoleão derrotado e a possibilidade de elaborar uma nova constituição, Benjamin Constant publica De l'esprit de conquête et de l'usurpation, um claro ataque às guerras napoleônicas. Já aparece aqui a comparação entre os antigos e os modernos. Nos dias 11 e 19 de março de 1815, enquanto Napoleão fugia da ilha de Elba, Constant publica dois artigos pedindo à nação que faça resistência contra o usurpador Napoleão, que havia prometido manter a paz e só fez a guerra. No dia 11 de março, Mme. de Staël deixa a França, pois chegava até Paris a notícia de que Napoleão voltaria à França. No dia 19 de março, Luis XVIII foge de Paris. Parece que Constant também teve um impulso de sair dali: deixa Paris e vai à Vendéia, mas volta. No dia 30 de março visita Bonaparte. Com o retorno do imperador, Constant se dispõe a colaborar, na esperança de Napoleão aceitar suas idéias. Aceita o convite, em abril, para redigir o Ato Adicional às Constituições do Império, em meio aos Cem-Dias, assim como o cargo de conselheiro do Estado. Como uma monarquia pode não ser tirânica? Este era seu desafio. Essa 
foi a pergunta que Mme. de Staël nunca lhe deixou de fazer, mesmo depois que já haviam se separado. Já não havia possibilidade de uma república. Em maio publica os Principes de Politique applicables à tous les gouvernements représentatifs et particulièrement à la Constituition actuelle de la France, mantendo grande parte da versão que escrevera em 1806, suprimindo, porém, o nome de Napoleão em diversas passagens, mas conservando a idéia original, e acrescentando uma parte que já estava pronta sobre o poder real neutro, além da última parte do título. Em junho Napoleão abdica pela segunda vez. Constant vai para Soissons e Haguenot como secretário da comissão encarregada de negociar com os aliados. No dia 5 de julho volta a Paris e entrega um relatório ao Governo Provisório, que é dissolvido dois dias depois. No dia 19 de julho Benjamin Constant recebe uma ordem de exílio, mas na semana seguinte Luis XVIII revoga essa ordem.

Pouco antes de Luis XVIII ser proclamado rei, Benjamin Constant se desespera, como vemos nas suas cartas, por não saber como se encaixar no novo governo. Pensa que o príncipe sueco, Bernadotte, também cotado para o cargo de rei da França, seria um aliado, e publica memoriais elogiosos a ele. Após a proclamação de Luis XVIII, em maio, publica as Reflexões sobre as constituições e as garantias em uma monarquia constitucional. A segunda Restauração o faz retornar ativamente à vida política. Trabalha como jornalista e é considerado um liberal de esquerda. Constant vai à Inglaterra, onde, em 1816, publica Adolfo.

Em março de 1819 Benjamin Constant é eleito deputado na Câmara, por Sarthe, ano também da Conferência sobre a liberdade dos antigos e modernos. É perseguido pelos Bourbon, sofre uma emboscada e é preso por seis meses, além de ter que pagar uma multa, é acusado de cumplicidade moral num complô contra os Bourbon. Perde a eleição em 1822, mas retorna à Câmara, eleito em 1824, desta vez por Paris, onde permanece com seu discurso crítico até a sua morte, em fins de 1830, alguns meses após a Revolução de julho. Apoiara Luís-Filipe, mas não viveu para gozar desse poder nem para fazer-lhe oposição, o que seria bem provável ${ }^{12}$.

\footnotetext{
${ }^{12}$ É apenas uma especulação, baseada na postura crítica que Constant assumiu durante sua vida. Poderia também seguir a postura de Guizot, alinhando-se ao liberalismo de governo. Durante este percurso não mencionei diversos aspectos da vida política e pessoal de Constant. As correspondências, o diário intimo, algumas outras obras publicadas, panfletos e discursos, bem como suas tão conturbadas relações com as mulheres poderiam ser
} 
Que reflexões podem ser formadas a partir dos controversos acontecimentos políticos desse período? Como se dá a recusa, num primeiro momento, à política de Robespierre, aos anos do Terror, e no momento seguinte à ditadura de Napoleão? Benjamin Constant nega a dependência extrema do indivíduo à política, isto é, à soberania do povo de Robespierre, mas também nega a independência total e isolada do indivíduo, que abre espaço para a ditadura de Bonaparte. A recusa da proposta da esquerda e da direita faz Constant pensar num termo médio: a liberdade individual junto à representação política num poder limitado. Benjamin Constant vivencia a Revolução ora à distância, estranhado, ora na ordem do dia, entranhado. Esse movimento de aproximação e distanciamento o faz olhar os acontecimentos através de lentes lúcidas ${ }^{13}$ - como observador e agente - a serviço do liberalismo. Do que é feito seu liberalismo, fonte de referência desta teoria política da história francesa que, em parte atualizada imediatamente em seguida por Tocqueville ${ }^{14}$ e que todavia encontramos traços até hoje? Que manobras são executadas pelo autor para fazer corresponder seu pensamento à sua prática? Que resultados tira da avaliação dos fatos que presencia de alguma forma e de muitos dos quais participa, quais suas ações e reações? Numa palavra, como vivencia o período pósrevolucionário? Ora, muitos aspectos do seu pensamento são modificados ou adaptados às circunstâncias ao longo desse percurso, sobretudo porque a própria realidade política sofria reviravoltas.

Certamente um aspecto permanece intacto, inabalável: a liberdade individual. Como o autor da Conferência sobre a liberdade dos antigos comparada à dos modernos, conhecido pela exaltação da liberdade-independência dos modernos em detrimento da liberdade de participação política direta dos antigos, contribui para fundar o liberalismo pósrevolucionário? Poderia um político calorosamente atuante, escritor engajado, un homme de

úteis para compreender, no detalhe, sua trajetória. Limitei ao que me pareceu essencial e busquei focalizar sua relação com a história politica vivenciada.

${ }^{13}$ Talvez não as mais lúcidas possíveis. Pierre Manent destaca que a lucidez de alguém que viveu tão de perto a Revolução, que, mais do que isso, vivenciou a sensação da história como autoridade máxima, deixou Benjamin Constant cego para perceber que Montesquieu dizia o mesmo que ele. Montesquieu queria estabelecer a autoridade da história, Constant a sentiu. Cf. Manent, Dez licões, capítulo 5.

${ }^{14}$ Há muitos traços comuns entre Alexis de Tocqueville e Benjamin Constant sobre a idéia de liberdade, igualdade e indivíduo. Com isso, aspectos da teoria liberal de Constant estão presentes em Tocqueville. Por outro lado, há aspectos diferentes, como a avaliação sobre a Revolução Francesa, ou a diferença de classe, um burguês e o outro aristocrata, dados que determinam perspectivas diferentes em suas concepções políticas. Não sabemos se Tocqueville chegou a ler propriamente Constant. Consta que na época da morte de Constant, Tocqueville desembarcava nos Estados Unidos da América para iniciar seus estudos sobre a democracia. 
lettres, assumir a liberdade individual como princípio supremo e desdenhar a liberdade de participação política, a que dá valor à sua própria prática? 


\title{
Capítulo 1: Liberdade antiga e moderna
}

\author{
I - A querela
}

Elaborar a comparação entre a liberdade dos modernos e a dos antigos não é um mérito apenas de Benjamin Constant, nem mesmo é ele o primeiro a fazê-la ${ }^{15}$. Aqui não trataremos dessa querela na sua abrangência e profundidade, apenas pretendemos entender como Constant a considerou e quais as suas contribuições para o conceito de liberdade individual. Tratada pelos estudiosos como uma querela (também ${ }^{16}$ ) da época da Revolução Francesa, cada autor abordou essa problemática de um ponto de vista diferente, e tanto escritores do século XVIII quanto alguns contemporâneos - alvos dos ataques de Constant

${ }^{15}$ Também não será a conferência de 1819 o primeiro lugar aberto por Constant para tratar da polêmica. Talvez este texto seja a forma mais acabada, mas encontramos muitos de seus elementos nos Princípios de Política, no momento da sua primeira redação em 1806. Sabe-se que Constant teria contribuído para o texto de Mme de Staël, Des Circonstances actuelles qui peuvent terminer la révolution, de 1799, em que a polêmica também está presente.

${ }^{16} \mathrm{O}$ problema de comparar os povos antigos e modernos já aparece muito antes. O período do Renascimento conferiu um lugar especial à cultura antiga e mesmo ali já aparecia a discussão sobre traduzir ou não as obras antigas para o francês. Destacamos o século XVII como o período de florescimento da polêmica entre antigos e modernos. Entre 1687 e 1715 há certo abalo no lugar que ocupa a cultura antiga; passa-se a questionar o seu caráter absoluto ao mesmo tempo em que se inicia uma conscientização do moderno. Um dos marcos iniciais dessa discussão se dá com Charles Perrault que, em 1687, lê seu poema Le siècle de Louis le Grand diante da Academia Francesa. Trata-se de uma apologia aos tempos contemporâneos e à monarquia francesa. Essa leitura foi considerada uma provocação pela maioria dos autores clássicos presentes. No ano seguinte, Perrault escreve Parallèle des anciens et des modernes, no qual explicita sua atitude comparativa. Ainda no século XVII, a querela tem dupla repercussão: no pensamento sobre a história e na estética. O pensamento histórico se desenvolve a partir da teoria do progresso em dois sentidos diferentes: pensar a história como um progresso linear, geralmente com um télos, ou um progresso cíclico, com períodos de decadência e ascenção. Dentre os que defendiam a história como um progresso linear, vale mencionar Fontenelle, pela obra Digression sur les anciens et les modernes, de 1688. O autor defende que a multiplicação dos conhecimentos deve garantir um progresso durável, mas recusa a comparação entre a espécie humana e o indivíduo: se o indivíduo se desenvolve por fases como a infância, a juventude ou virilidade e depois a velhice e a morte, não se passa o mesmo com a espécie humana. A humanidade não tem velhice e morte, pois a espécie não se degenera jamais. A Idade Média é explicada como um momento de "amnésia temporária" ou "doença curável" no meio do progresso. Constant, diferente de Fontenelle, faz essa comparação, mas também não acredita que caminhamos para a velhice e morte, mas antes para a igualdade. A querela também se constitui pelos partidários dos antigos, como Boileau, Racine, La Fontaine, La Bruyère, Arnault etc. Defendem, basicamente, que os antigos são modelos de simplicidade e integridade, já os modernos cultuam o luxo, que leva aos vícios. Na estética, a querela se dá entre aqueles que cultuam a bondade como valor absoluto e definível pelas normas, buscando as regras para o bom gosto. Os opositores tentaram mostrar que os modernos têm valores específicos, que a bondade pode ser relativa. Certamente Constant se inteirou dessa polêmica, tanto pelos citados Montesquieu, Rousseau, Mably e Condorcet, quanto provavelmente por Hume e Voltaire. Durante a Revolução, destaca-se o texto de Chateaubriand, Ensaio histórico sobre as revoluções, de 1797, entendendo a Revolução Francesa como um retorno à Antiguidade. A polêmica também ultrapassa o contexto da Revolução, como se pode conferir em Taine e outros autores do XIX. 
nessa questão - tornaram-se os responsáveis por aclamar a liberdade dos antigos em tempos modernos. Terrível ilusão anacrônica, dirá Constant.

Podemos reivindicar a liberdade dos antigos em tempos modernos? Que lugar deve ocupar o passado? Se nos perguntarmos pelo sentido de reviver essa referência antiga, no momento da Revolução Francesa, a qualquer um daqueles que tomou partido a favor ou contra a questão, corremos o risco de sair do caminho proposto. Mesmo assim, não deixa de ser curiosa a questão, uma vez que os homens do fim do século XVIII já haviam bebido na fonte dos antigos, tomada como parte de qualquer formação erudita - retórica escolar -, ao mesmo tempo em que já haviam respirado a atmosfera dos enciclopedistas e, portanto, uma vivência referencial mais moderna. O que nos parece importante aqui é notar que justamente alguns desses modernos, sobretudo Rousseau, retomam a tradição clássica, Rousseau, por sua vez, é a grande referência dos homens da Revolução, seja para o partido que for: à esquerda ou à direita da Assembléia, todos se apropriaram das idéias de Rousseau. Ou seja, seria discutível tanto a leitura que os revolucionários fizeram da noção de liberdade dos antigos, quanto o uso e interpretação da obra de Rousseau.

Nesse contexto, a polêmica na época, nomeada como a lógica do qüiproquó, por François Hartog ${ }^{17}$, refere-se ao procedimento de fazer um curto-circuito no tempo. Toma-se uma ponta do fio da história e pretende-se amarrá-la na outra extremidade. Esse choque é denunciado pelos adversários das decisões políticas de Robespierre, como Benjamin Constant, fundamentados na noção de progresso da história. Este curto-circuito, segundo Hartog, é um grande mal-entendido e ainda cai no erro de sobrepor um tempo a outro:

Qual é, ao todo, o estatuto da referência antiga quando proclamada pelos revolucionários? Procedente da história monumental ${ }^{18}$, fundamentalmente

\footnotetext{
${ }^{17}$ HARTOG, François. $\quad$ Da liberdade dos antigos à dos Modernos: o momento da revolução francesa. $\quad$ As referências bibliográficas completas encontram-se na bibliografia, ao final do texto.

${ }^{18}$ A expressão "história monumental" é emprestada de Nietzsche. Se a história é tratada como monumento, então o passado serve para ser imitado. Mas essa imitação do passado deve ser feita tanto pelo que houve de grandioso quanto pelos erros, a fim de superá-los. "Se a grandeza passada foi possível ao menos uma vez, ela será ainda possível no futuro", mas a história momumental "nos engana por meio de um jogo de analogias" (Nietzsche, Considerações extemporâneas, citado por Hartog). Ao fazer analogias entre o passado e o presente, podemos cair no engano de aproximar aquilo que não é semelhante, e, assim, tornar monumental ou exemplar um efeito em prejuízo da causa, por isso a analogia pode lesar o passado.
} 
analógica, ela obedece, além do mais, a uma lógica do qüiproquó. Curtocircuitando o tempo, ela faz literalmente vir o 'passado' no presente, instala-o no lugar, quando não em lugar do presente. O ganho, para os revolucionários, é poder 'reconhecer-se', por exemplo em Licurgo, e encontrar palavras para dizer o inédito de sua própria ação. Ela é também qüiproquó no sentido ordinário de mal-entendido, já que a coisa não funciona nem para o passado nem para o presente (as analogias 'lesam' tanto um quanto outro), mas um mal-entendido produtor de efeitos: uma visão do mundo antigo (que se poderá partilhar ou que exigirá esforço em recusar) e uma maneira de compreender, portanto de dizer e de fazer o presente. (HARTOG, 2002, p. 156, grifos nossos).

O fundo dessa polêmica, que sobreviveu à questão da época, é pensar o lugar do passado. Reconhecem os estudiosos que a contribuição ${ }^{19}$ de Constant vai além da querela, pois ele não considera que a liberdade antiga ainda seja possível, nem que se possa passar de uma à outra. Sobretudo, afasta-se da tendência da época de fazer uma história da Antiguidade: Constant está preocupado com o presente.

Esse engano tornou-se útil na Revolução Francesa para aqueles que propunham o retorno ao modelo antigo de liberdade - a participação política direta - somado à idéia rousseauísta de soberania do povo. Qual é o problema desta proposta, além de ser considerada anacrônica? Qualquer crítico da Revolução poderia condená-la. Mas Benjamin Constant sempre esteve ao lado da Revolução, e não foi apenas pelo caráter anacrônico que julgou e condenou o retorno à liberdade antiga. Naquela noite de fevereiro de 1819, ninguém poderia se levantar para acusar Constant de anti-revolucionário. Que manobras nosso autor executou para fazer a crítica liberal à Revolução sem destruir a proposta de 1789 ?

Na famosa conferência no Athénée Royal ${ }^{20}$ de Paris, em 1819, Benjamin Constant traça um quadro comparativo entre o que teria sido a liberdade para os povos antigos e o que é a liberdade para os modernos. Mais do que isso, neste texto reúne elementos de sua teoria política, que já havia publicado em De L'esprit de Conquête et De L'usurpation, em 1814, e nos Princípios de Política, em 1815, compondo seu sistema liberal.

\footnotetext{
${ }^{19}$ De acordo com Todorov, a querela é antiga, mas o sentido da oposição, em Constant, é diferente. A fonte imediata de Constant seria Condorcet, nas palavras de Todorov: "A maioria, mesmo se é legítima, não deve poder invadir o território do indivíduo; ora, só os modernos descobriram esse princípio". TODOROV, T. Benjamin Constant, la passion démocratique. Tradução livre. p. 42. Condorcet inspira Constant porque trata da categoria da representatividade para afastar e romper a relação entre antigos e modernos.

${ }^{20}$ As citações do texto A liberdade dos antigos comparada à dos modernos são da tradução de Loura Silveira e serão indicadas pelas palavras "antigos e modernos" seguidas da página correspondente.
} 
Benjamin Constant parte da tese de que a condição da espécie humana, precisamente a organização social de um povo, a leva a desejar um sistema político específico, e a torna incapaz de desejar algum outro que não seja autorizado pelo seu tempo. Ou seja, a liberdade moderna é mais adequada à nossa natureza, mas só é possível nesse momento histórico. Há, portanto, uma teoria do progresso em Constant, que admite a dupla autoridade: natureza e história. Esta questão será desenvolvida no próximo capítulo.

$\mathrm{Na}$ teoria, Constant anuncia sua crítica ao problema da antecipação ou anacronismo, ou seja, a crítica à manutenção de critérios antigos para reivindicar a liberdade presente. $\mathrm{Na}$ prática, poderia atingir as reações jacobinas à Revolução, justificadas na Antiguidade clássica $^{21}$. Ou, também, aos anos do império napoleônico, tempos de guerra e prejuízo das liberdades. É a partir desse contexto que Benjamin Constant forma o seu conceito de liberdade para os tempos modernos. Por que não podemos nos valer mais da liberdade tal como foi apreciada pelos antigos? Trata-se de um ímpeto moderno, mais "revolucionário" que os jacobinos, um anticonservadorismo? Ou o problema da antecipação é uma arma de estratégia política contra a circunstância dos anos do Terror? Estaria Constant apenas denunciando a retórica jacobina, fundada no fanatismo da liberdade política? A liberdade política justificava-se na participação e na desejada soberania do povo de Robespierre. Essa liberdade à moda antiga trazia consigo a idéia de virtude, participação ativa nas decisões políticas, a exigência de cada um ser um agente, um cidadão, mas também rompia com o sistema hereditário do Antigo Regime. Fundamentada, assim, na virtude do cidadão, a liberdade antiga estava plenamente justificada nos primeiros anos da Revolução. Mas na noite em que Constant exibe sua Conferência, o Terror já há muito deixara de ser uma ameaça presente. São os tempos posteriores à Napoleão ${ }^{22}$, já sob a Restauração, e os inimigos do nosso autor nesse momento estão à direita, são os ultramonarquistas e os monarquistas moderados. É a ameaça de outra ditadura, do cerceamento da liberdade individual e da apatia

\footnotetext{
21 "O mundo está vazio desde os romanos; e a memória deles o preenche, e profetiza ainda a liberdade." SaintJust, citado por Hartog, idem, p. 168.

${ }^{22}$ De acordo com Hofmann: "Les différences qu'il observe entre les anciens et les modernes donnent à Constant l'occasion de s'en prendre à un adversaire autrement plus redoutable que les éscrivains qui le servent: Napoléon" (HOFMANN, 1980, p. 350).
} 
da liberdade política, enfim, o risco da passividade cívica. É também o medo dos ultramonarquistas abolirem as eleições, daí também a defesa da representação política.

\section{II - As duas liberdades}

Na conferência no Athénée Royal há uma primeira definição de liberdade que Benjamin Constant atribui ao senso comum ${ }^{23}$ dos homens modernos. Participam dessa definição tanto aspectos individuais quanto direitos políticos: é essencialmente a liberdade individual perante o espaço público, ou ainda, a liberdade do indivíduo agir como quiser, independente da autoridade política, garantindo-se contra os abusos do poder. "É o direito de não se submeter senão às leis, de não poder ser preso nem detido, nem condenado nem maltratado de nenhuma maneira, pelo efeito da vontade arbitrária de um ou de vários indivíduos", ou seja, é a afirmação do fim do Antigo Regime, das lettres de cachet, e também dos abusos do poder arbitrário dos anos do Terror e das perseguições do imperador. "É para cada um o direito de dizer sua opinião, de escolher seu trabalho e de exercê-lo; de dispor de sua propriedade, até de abusar dela; de ir e vir, sem necessitar de permissão e sem ter que prestar conta de seus motivos ou de seus passos." Constant defendeu insistentemente a liberdade de imprensa ao longo de toda a sua carreira, assim como o direito à propriedade privada; direitos que compõem a liberdade individual. "É para cada um o direito de reunir-se a outros indivíduos, seja para discutir sobre seus interesses, seja para professar o culto que ele e seus associados preferirem, seja simplesmente para preencher seus dias e suas horas de maneira mais condizente com suas inclinações, com suas fantasias." Trata-se da liberdade religiosa, também amplamente defendida por Constant, e da liberdade de gozar dos interesses privados que cada um desejar, característica essa, ressaltará Constant, típica dos tempos

\footnotetext{
${ }^{23}$ Isso que chamamos "senso comum dos homens modernos" no texto está diferente. Na Conferência está assim: "Demandez-vous d'abord, Messieurs, ce que de nos jours un Anglais, un Français, un habitant des États-Unis de l'Amerique, entendent par le mot de liberté?". Não é por acaso que se refere aos habitantes dos Estados Unidos da América, pois seu processo de independência foi fortemente marcado pela defesa dos Bills of Rights. Inclusive La Fayette, que apresentou o projeto dos Direitos na Revolução Francesa, foi um dos heróis da independência americana. Os ingleses já haviam declarado o freeborn englishmen, que embora não fosse universal, trazia já a idéia desses direitos. Os franceses já haviam passado pela experiência da Declaração Universal dos direitos do homem e do cidadão, no início da Revolução, de modo que é justamente nesses três países que encontraríamos a definição de direitos que segue na citação.
} 
modernos. "Enfim, é o direito, para cada um, de influir sobre a administração do governo, seja pela nomeação de todos ou de certos funcionários, seja por representações, reivindicações, às quais a autoridade é mais ou menos obrigada a levar em consideração" (CONSTANT, antigos $e$ modernos, p. 10). Apenas no final é mencionada a liberdade política, o direito de participação e de expressão de opiniões políticas.

De um modo geral, é a liberdade de o indivíduo fazer o que quiser sem a intervenção do Estado, supondo a existência de um governo representativo. Especificamente, Constant procura proteger o indivíduo e sua vida particular da arbitrariedade do poder. Portanto, essa liberdade moderna se desdobra no campo público e no privado, com muito mais força neste último. Estrategicamente, trata-se de consolidar as conquistas da Revolução contra o absolutismo do Antigo Regime, pontuar os problemas enfrentados pelos anos do Terror no início da Revolução e garantir-se contra a ditadura dos ultramonarquistas. Além da crítica, ainda consegue sutilmente posicionar-se de modo a salvar aspectos da Revolução, do império napoleônico e não se indispor com os monarquistas moderados.

Já a liberdade dos antigos é essencialmente a liberdade política, de ser um cidadão que atua no espaço público, que delibera mas ao mesmo tempo, admite submeter "o indivíduo à autoridade do todo" (CONSTANT, antigos e modernos, p.11). Constant estabelece essa aparente contradição interna da liberdade dos antigos, mostrando que o homem é, por um lado, como cidadão, livre nas questões públicas, e por outro, como indivíduo, "escravo em todos os assuntos privados" (CONSTANT, ibidem). A contradição inversa também se coloca nos tempos modernos: o indivíduo é livre na sua vida privada, mas "só é soberano em aparência". O que sustenta essas contradições? Parece que a inversão se dá na relação entre indivíduo e sociedade política, privado e público, ou, de outro modo, entre costumes e leis. Se, no caso dos antigos, "as leis regulamentavam os costumes e, como tudo dependia dos costumes, não havia nada que as leis não regulamentassem" (CONSTANT, ibidem), então, podemos afirmar que no caso dos modernos os costumes regulamentam as leis?

Justamente porque o indivíduo moderno tem desejo de independência, é necessário instituir o direito à liberdade individual? Com isso, a época moderna anuncia não só a valorização do privado, mas também um campo jurídico dependente e determinado pelo 
indivíduo. Já para os antigos, a relação é inversa: a liberdade é política justamente porque a supremacia do público determina a esfera privada. Mas por que houve essa inversão?

Quatro grandes razões explicam a diferença entre os antigos e os modernos na Conferência de 1819, a saber: a relação entre a extensão territorial e a dimensão política; a escravidão e o tempo livre; os encargos comerciais e a ociosidade; o comércio independente e a intervenção do governo. São aspectos econômicos, históricos, geográficos e culturais que determinam a distância entre as formas de liberdade dos dois povos, de modo que se torna impossível retroceder, ou, ainda, "desfrutar" daquela liberdade política.

Os antigos se reuniam em cidades pequenas e próximas umas das outras, por isso, "o espírito dessas repúblicas era belicoso; cada povo incomodava continuamente seus vizinhos ou era incomodado por eles" (CONSTANT, antigos e modernos, p. 12). Ou seja, justamente por serem povos pequenos e próximos, faziam do combate seu ofício: "Todos compravam a segurança, a independência, a existência inteira ao preço da guerra" (CONSTANT, ibidem). Outra conseqüência que Benjamin Constant extrai daí é a escravidão, a mão-de-obra mecânica era confiada a "mãos acorrentadas" para produzir os artefatos bélicos.

Já os modernos, organizados territorialmente de outra forma, com Estados mais vastos, diversificaram a sociabilidade: "Uma massa de homens existe agora sob diferentes nomes", mas "essencialmente homogênea. Ela é suficientemente forte para não temer hordas bárbaras. É suficientemente esclarecida para não querer fazer a guerra. Sua tendência é para a paz" (CONSTANT, ibidem). Daí segue-se a última conseqüência: os modernos não fazem a guerra, fazem o comércio, que é uma forma também de conquistar o que se deseja, mas não pela violência: "A guerra é o impulso, o comércio é o cálculo" (CONSTANT, ibidem, p.13).

Estas são as diferenças gerais entre antigos e modernos. Constant demonstra, então, os resultados dessas distinções. O primeiro resultado se infere da diferença da extensão territorial, pois num Estado grande, a importância de cada indivíduo é muito menor do que num Estado pequeno, onde o cidadão, como era o caso dos antigos, tem expressão notória, é observado por todos. Já nos Estados extensos dos modernos "sua influência pessoal é um elemento imperceptível da vontade geral que imprime ao governo sua direção" (CONSTANT, ibidem, p. 14). Veremos, mais adiante, como Constant entende as noções de vontade geral e 
de soberania do povo, muito importantes para sua teoria política. O segundo resultado advém da escravatura. Os antigos sustentavam materialmente a participação política direta no trabalho escravo: "Sem a população escrava de Atenas, vinte mil atenienses não teriam podido deliberar cada dia na praça pública" (CONSTANT, idem), ao passo que os modernos, com a abolição da escravatura, precisam usar seu tempo para o trabalho. O terceiro resultado se extrai do avanço do comércio em detrimento da guerra. A atividade da guerra, tão praticada pelos antigos, oferece intervalos de tempo entre uma batalha e outra, o que proporcionava aos antigos longos períodos de inatividade e de ócio, necessários para fomentar discussões políticas. O último resultado se refere à relação entre o comércio e a independência individual, reforçando com contornos mais nítidos a teoria liberal de Constant:

\begin{abstract}
Finalmente, o comércio inspira aos homens um forte amor pela independência individual. O comércio atende a suas necessidades, satisfaz seus desejos, sem a intervenção da autoridade. Esta intervenção é quase sempre, e não sei por que digo quase, esta intervenção é sempre incômoda. Todas as vezes que o poder coletivo quer intrometer-se nas especulações particulares, ele atrapalha os especuladores. Todas as vezes que os governos pretendem realizar negócios, eles o fazem menos bem e com menos vantagens do que nós (CONSTANT, Ibidem).
\end{abstract}

Até aqui estão explicados os motivos das condições materiais ${ }^{24}$ da irreversibilidade do processo histórico, ou seja, são motivos empíricos e externos suficientes que impedem os modernos de desejar a liberdade dos antigos. Parece também que há algo da ordem das paixões do indivíduo moderno que impossibilita o retorno àquela liberdade política. Trataremos dessa perspectiva no último capítulo.

O que resta aos modernos, propõe Constant, é regular a liberdade individual. "Nossa liberdade deve compor-se do exercício pacífico da independência privada" (CONSTANT, antigos e modernos, p. 15). Contudo, as determinações das diferenças entre antigos e

\footnotetext{
${ }^{24}$ Segundo Manent, não é tanto a idéia da irreversibilidade histórica, fundada nas enormes diferenças do Estado social, que sustenta o problema do anacronismo, pois se assim fosse, poderíamos supor uma civilização no futuro com as mesmas condições que as antigas. É, sobretudo, a análise psicológica feita por Constant que impossibilita o retorno à Antiguidade. Tendemos a discordar nesse ponto porque a própria idéia de progresso de Constant nos parece mais linear do que cíclica. No entanto, concordamos com Manent sobre a importância do critério psicológico do indivíduo moderno para compor a comparação.
} 
modernos não são apenas obra do tempo. Constant afirma que oprimir a independência individual não é vantajoso para o moderno, porque o indivíduo não vai usufruir da liberdade política. Tanto porque sem a liberdade individual não há liberdade política quanto porque em tempos modernos não é possível alcançar uma liberdade de um tempo passado. Ou seja, além da liberdade individual ser o desejo determinante do homem moderno, é também uma vantagem, pois é pensada após um cálculo de perdas e ganhos. Para os antigos há uma compensação ${ }^{25}$ para o sacrifício da individualidade, inclusive, infere o autor, a liberdade individual não lhes deveria ser muito cara.

Conclui-se que devemos ser bem mais apegados que os antigos à nossa independência individual. Pois os antigos, quando sacrificavam essa independência aos direitos políticos, sacrificavam menos para obter mais; enquanto que, fazendo o mesmo sacrifício, nós daríamos mais para obter menos (CONSTANT, ibidem).

No limite, o indivíduo moderno não ganha com essa negociação porque não ficará satisfeito. Como um homem perdido na multidão, "o exercício dos direitos políticos somente nos proporciona pequena parte das satisfações que os antigos nele encontravam e, ao mesmo tempo, os progressos da civilização, a tendência comercial da época, a comunicação entre os povos multiplicaram e variaram ao infinito as formas de felicidade particular" (CONSTANT, ibidem). Desse modo, se a liberdade dos antigos é definida como a "partilha do poder social entre todos os cidadãos de uma mesma pátria", ao passo que, para os modernos, mais vale "a segurança dos privilégios privados; e eles chamam de liberdade as garantias concedidas pelas instituições a esses privilégios" (CONSTANT, antigos e modernos, pp. 15-16), então podemos inferir que a definição de liberdade moderna passa necessariamente pelo âmbito do indivíduo, na instância privada e civil, ao passo que os antigos gozavam de uma liberdade essencialmente política. No fundo, a relação se dá entre a organização social de um povo e seu desejo por um sistema político que os beneficie. No caso dos modernos, há que se pensar

\footnotetext{
${ }^{25}$ Compensação e vantagens parecem termos do vocabulário do comércio e dos negócios. Constant utiliza esse vocabulário frequentemente para referir-se ao campo psicológico do indivíduo e suas relações com a liberdade.
} 
num sistema político (não uma forma de governo, como monarquia ou república) que garanta a liberdade individual e não exija uma participação política tão entranhada e intensa como no modelo antigo. $\mathrm{O}$ que ocorre quando alguns modernos desejam um sistema de liberdade antigo?

Este é o caso de alguns homens da Revolução Francesa que, inspirados por Rousseau e sobretudo pelo abade de Mably, no início do processo revolucionário, erraram, num primeiro momento, vítimas da nostalgia e da ingenuidade. Constant entende o que move o erro e os desculpa, ironicamente, já que, hoje em dia, "não se consegue ler as belas páginas da Antigüidade, não se revivem as ações desses grandes homens sem experimentar uma emoção muito especial que nada do que é moderno nos faz sentir", de modo que "é impossível não desejarmos imitar o que invejamos". (CONSTANT, antigos e modernos, p. 16). A ironia é a arma da crítica ${ }^{26}$ de Constant, mais moderada contra Rousseau e mais severa contra Mably.

Esse é o erro de alguns revolucionários, pois o homem moderno de Benjamin Constant não sustenta mais essa ingenuidade, o entusiasmo pelo o que ele sabe que não pode mais viver. Não temos mais esse entusiasmo pelas grandes convicções dos antigos, ao contrário, somos frouxos e oscilantes politicamente ${ }^{27}$.

Se Constant desculpa esses primeiros guias da Revolução, não é com a mesma piedade crítica que trata daqueles que serviram de influência aos revolucionários (e também a

\footnotetext{
${ }^{26}$ Sobre Rousseau, Constant declara na Conferência: "Evidentemente, salientando o que considero como um engano importante a revelar, serei ponderado em minha refutação e respeitoso em minha crítica. Evitarei, é claro, juntar-me aos detratores de um grande homem. Quando o acaso me faz aparentemente concordar com eles em um único ponto, desconfio de mim mesmo; e, para consolar-me de parecer, por um instante, de sua opinião, sobre uma única e parcial questão, preciso desautorizar e descolorir quanto posso a esses supostos auxiliares". Ao comparar Rousseau com Mably, Constant diz: "Aliás, não é a Rousseau, como veremos, que se deve principalmente atribuir o erro que vou combater: ele pertence muito mais a um de seus sucessores, menos eloqüente, mas não menos austero; e mil vezes mais exagerado". Assim, Rousseau recebe críticas de Constant, mas também elogios, pois o princípio da soberania do povo de Rousseau é muito respeitado pelo nosso autor; já ao abade de Mably cabe todo desdém.

${ }^{27}$ Foi justamente o que fez Robespierre, pela análise crítica de Benjamin Constant. Isso confere com a descrição feita por Patrice Gueniffey, no Dicionário Crítico da Revolução Francesa, organizado por Furet. Robespierre é responsabilizado pela arbitrariedade do poder ("é necessário fazer com que os traidores regressem ao nada", disse em 28 de maio de 1793 à Convenção. O confronto terminaria na Convenção pelo indiciamento dos Girondinos, em 2 de julho do mesmo ano). Também nota-se como é oscilante, ou ainda, contraditório, quando, por exemplo, estava favorável em 27 de agosto de 1792 ao direito que assistiria às assembléias primárias de rever as opções feitas pela assembléia do segundo grau; Robespierre, eleito em 5 de setembro, mudou de opinião no dia 9. Enfim, é responsabilizado por sistematizar e legitimar o Terror.
} 
ele mesmo); Jean-Jacques Rousseau, Abade de Mably e Montesquieu ${ }^{28}$. Deixemos de lado a questão da validade da leitura de Constant dos filósofos, pois o que estamos discutindo são suas idéias e não suas leituras ${ }^{29}$. Suas críticas e aceitações às teorias dos filósofos vêm desde 1806, na redação dos Princípios de Política. Na conferência sobre os antigos e os modernos apenas atira algumas flechas irônicas. Chama Rousseau de "gênio sublime" e sua obra de "metafísica". Aponta o problema de transportar valores - poder social e soberania coletiva de outros séculos, e termina com uma acusação que já desenvolvera nos Princípios: Rousseau, "animado pelo amor puro à liberdade, forneceu, todavia, desastrosos pretextos a mais de um tipo de tirania" (CONSTANT, antigos e modernos, p. 16). Ao abade de Mably, "austero e intolerante", cabe a responsabilidade por fazer exatamente o oposto de seu projeto nesta conferência, ou seja, reivindicar a liberdade antiga em tempos modernos, ao querer que o indivíduo seja escravo para que o povo seja livre e, assim, a nação soberana. Tanto Rousseau quanto Mably são acusados de usar meios quaisquer para justificar um fim justo, qual seja, tomar a autoridade do corpo social para justificar a liberdade. Para Montesquieu é reservada uma crítica mais leve, pois é um "espírito observador", com a "cabeça menos ardente". O problema de Montesquieu foi diferenciar a república da monarquia quando o caso era diferenciar antigos de modernos.

\section{III - A liberdade moderna}

Ainda nos Princípios de Política encontramos um capítulo sobre a inviolabilidade das propriedades, outro sobre a liberdade religiosa, um sobre a liberdade de imprensa e um sobre a liberdade individual. São quatro capítulos que desenvolvem os temas da liberdade, também ${ }^{30}$ apresentados na obra publicada em 1814, De L'esprit de conquête et de l'usurpation, em diversos panfletos e em outros escritos publicados postumamente.

\footnotetext{
${ }^{28}$ No capítulo Da soberania do povo , nos Princípios de Política , Constant também se refere a Hobbes, acusando-o de ter acrescentado o caráter absoluto na soberania do povo. O esforço de Constant está em relativizar as expressões de Hobbes.

${ }^{29} \mathrm{Na}$ época não havia essa exigência que temos hoje de fazer uma leitura exata de um filósofo predecessor.

${ }^{30}$ É bastante comum vermos passagens muito semelhantes ou até copiadas nos escritos de Benjamin Constant. É traço marcante de sua obra a repetição dos argumentos.
} 
O direito à propriedade privada faz parte da convenção social, diz Constant. Não é natural, muito menos abstrato, mas nem por isso deixa de ser um direito inviolável e necessário. Sem propriedade, a humanidade não se desenvolve. Diferente da liberdade, da vida e da opinião, a propriedade está sujeita às leis do Estado, mas essas leis têm limites, pois não podem causar danos ao proprietário. O imposto cobrado sobre a propriedade é um mal necessário, então é preciso torná-lo o menor possível, até mesmo porque o excesso de impostos pode destruir a liberdade individual. Ou seja, com impostos abusivos, o povo tornase miserável, tanto financeira quanto moralmente, pois os impostos arrecadados não serão utilizados para garantir a paz na sociedade, ao contrário, serão usados para fazer a guerra:

\begin{abstract}
Assim, o povo não é miserável apenas por pagar além dos seus meios, mas é miserável também pelo uso que fazem do que paga. Seus sacrifícios se voltam contra ele. Ele não paga mais impostos para ter a paz garantida por um bom sistema de defesa; paga para ter a guerra, porque a autoridade, orgulhosa com seus tesouros, quer gastá-los gloriosamente. $O$ povo não paga para que a boa ordem seja mantida no interior, mas ao contrário, para que os favoritos enriquecidos com seus despojos perturbem a ordem política com vexações impunes. Desse modo, uma nação compra, por suas privações, as desgraças e os perigos; e, nesse estado de coisas, o governo se corrompe por sua riqueza, e o povo por sua pobreza (CONSTANT, 2005 ${ }^{31}$, pp.129-130).
\end{abstract}

Constant está preocupado em manter o princípio da paz, a segurança, e ao mesmo tempo afirma a propriedade como um direito e a necessidade de que os impostos sejam moderados. Condena qualquer perspectiva de socialização da propriedade, mostrando, mais uma vez, sua veia liberal.

Alguns filósofos consideraram seu estabelecimento [da propriedade privada] um mal, sua abolição, possível; mas recorreram, para fundamentar suas

\footnotetext{
31 "Ainsi, le peuple n'est pas misérable seulement, parce qu'il paie au-delà de ses moyens, mais il est misérable encore par l'usage que l'on fait de ce qu'il paie. Ses sacrifices tournent contre lui. Il ne paie plus des impôts pour avoir la paix assurée par un bon système de défense. Il en paie pour avoir la guerre, parce que l'autorité fière de ses trésors, veut les dépenser glorieusement. Le peuple paie, non pour que le bon ordre soit maintenu dans l'interieur, mais pour que des favoris enrichis de ses dépouilles troublent au contraire l'ordre public par des vexations impunies. De la sorte, une nation achète, par ses privations, les malheures et les dangers; et dans cet état de choses, le gouvernement se corrompt par sa richesse, et le peuple par sa pauvreté" (CONSTANT, 1997, p. 456).
} 
teorias, a uma multidão de suposições, algumas das quais podem nunca se realizar e as menos quiméricas das quais estão relegadas a uma época em que nos é permitido prever (CONSTANT, 2005, p. 117).

Desse modo, Benjamin Constant faz duas críticas a respeito da propriedade privada: ao Estado que tributa abusivamente os contribuintes e às propostas de socialização ou abolição da propriedade privada.

A liberdade de imprensa é um tema caro a Constant, amplamente desenvolvido em diversos panfletos ao longo de sua carreira. Nos Princípios de Política o autor apenas toca no ponto em que se tornou polêmica sua defesa da liberdade de imprensa. Concorda com a atual Constituição (de Napoleão) quanto à submissão dos delitos de imprensa a um júri. A liberdade de imprensa tem o seguinte limite: não se pode atacar a pessoa do imperador. Mesmo na Inglaterra onde a liberdade de imprensa é a mais destacada, não se permite atacar o rei sem severas punições. Seu argumento é o seguinte: o imperador (ou rei) está protegido pela neutralidade do poder, assim como os cidadãos estão protegidos pelas garantias individuais. Há uma lei de reciprocidade, na qual o poder do soberano não pode agir contra os cidadãos, assim como estes não podem agir contra o poder real. Além disso, é preciso distinguir a pessoa do imperador do seu poder. Quando se agride o imperador publicamente, na verdade, o cidadão ataca o poder, não a pessoa, e fere, portanto, a neutralidade do poder real. Conseqüentemente, o cidadão ataca a Constituição, pois o imperador poderá atacar a liberdade daquele cidadão. Nas palavras de Constant:

O rei, na Inglaterra, o imperador, na França, o depositário da autoridade monárquica, em todos os povos, estão fora da esfera das agitações políticas. Não são homens, são poderes. Mas, assim como eles não devem voltar a ser homens, senão sua função seria desnaturada, tampouco se pode aceitar que sejam atacados como outros homens. A lei garante os cidadãos contra toda agressão por parte deles, ela também deve garanti-los contra toda agressão por parte dos cidadãos. Ultrajado em sua pessoa, o chefe de Estado torna-se 
novamente um homem. Se você ataca o homem, o homem se defenderá, a Constituição será destruída" (CONSTANT, 2005 ${ }^{32}$, p. 133).

Portanto, os escritos incendiários, os libelos, tão freqüentes na época, devem ser penalizados porque, em última instância, abrem uma brecha para que as liberdades individuais sejam violadas, através do movimento de reciprocidade.

Resta ainda destacarmos outra liberdade, igualmente muito cara a Constant: a liberdade religiosa. De acordo com a Constituição do Império - a qual Benjamin Constant elogia ${ }^{33}$-, a liberdade de culto se dá sem restrições, sem privilégios e sem obrigar o cidadão a declarar publicamente sua escolha religiosa. Critica Rousseau, novamente pelo princípio da liberdade individual, sobre a idéia do Estado determinar uma profissão de fé civil aos cidadãos: "O que é o Estado, para decidir dos sentimentos que se têm de adotar? Que me importa que o soberano não me obrigue a crer, se me pune por eu não crer?" (CONSTANT, 2005, pp. 134-135). Aqui há uma distinção entre intolerância civil e religiosa, ambas perigosas, diz o autor, mas a civil é ainda mais absurda, mais injusta, porque pune os indivíduos sem convicção alguma, apenas por um exercício de cálculo do poder, não por um dever moral. A religião é, desse modo, para o nosso autor, algo que vem da natureza, não da sociedade, e é individual. A autoridade não pode intervir nesse campo interior ao indivíduo, tão íntimo quanto nossas emoções e paixões. Religião e Estado devem estar separados de vez, diz Constant, unidos apenas no vínculo pecuniário, mesmo assim restrito. O Estado não deve remunerar todo o clero, mas apenas alguns padres de comunidades mais numerosas, e as seitas menores ou novas podem ser mantidas pelos próprios fiéis. "Vale para a religião o

\footnotetext{
32 "La neutralité du pouvoir royal, cette condition indispensable de toute monarchie constitutionelle, à laquelle je reviens sans cesse, parce que toute la stabilité de l'edifice repouse sur cette base, exige également que ce pouvoir n'agisse pas contre les citoyens, et que les citoyens n'agissent pas contre lui. Le roi, en Anglaterre, l'empereur, en France, le dépositaire de l'autorité monarchique chez tous les peuples, sont hors de la sphère des agitations politiques. Ce ne sont pas des hommes, ce sont des pouvoirs. Mais de même qu'il ne faut pas qu 'ils redeviennent des hommes, sans quoi leur fonction serait dénaturée, il ne faut pas non plus qu'ils puissent être attaqués comme d'autres hommes. La loi garantit les citoyens de toute agression de la part des citoyens. Outragé dans sa personne, le chef de l'État redevient un homme. Si vous attaquez l'homme, l'homme se défendra, la contituition sera détruite" (CONSTANT, 1997, p. 459).

33 "A questão da liberdade de imprensa foi tão bem esclarecida de uns tempos para cá, que só cabe um pequeno número de observações. A primeira é que nossa Constituição atual se distingue de todas as precedentes pelo fato de ter estabelecido o único modo eficaz de reprimir os delitos de imprensa, deixando-lhe sua independência, a saber, o julgamento por um júri. É uma grande prova, ao mesmo tempo, de lealdade e de luzes" (CONSTANT, 1997, p. 131).
} 
mesmo que para as grandes estradas: gosto que o Estado as mantenha, contanto que deixe a cada um o direito de preferir os pequenos caminhos e veredas..." (CONSTANT, 2005 $5^{34}$, p. 152).

São basicamente estes os aspectos da limitação do poder que Constant reivindica. Isso também quer dizer que não adianta dividir o poder para limitá-lo, o que sugere a leitura crítica que Constant faz de Montesquieu, pois "se a soma total do poder é ilimitada, os poderes divididos só necessitam formar uma coalizão, e o despotismo é inevitável" (CONSTANT, ibidem). Os poderes não podem ser violados de modo algum, por isso não adianta que um poder vigie outro, é preciso mesmo limitá-lo na sua totalidade, embora Constant tenha elaborado a teoria do poder neutro, que, de alguma forma, tem a função de regular os outros. A objeção que podem fazer, dirá Constant, não é pela divisão ou não do poder, por questões de organização do poder, mas por encontrar uma limitação meramente abstrata. Contra isso é preciso impor-se a força da opinião pública, ou ainda, "quando determinados princípios são completa e claramente demonstrados, eles servem de certo modo de garantia a eles mesmos" (CONSTANT, ibidem, p. 16).

Assim, um dos problemas da Revolução foi exaltar a vontade coletiva em prejuízo da liberdade individual, "sem, contudo, destruir-lhe a necessidade" (CONSTANT, antigos $e$ modernos, p. 18). Colocada em termos de necessidade ${ }^{35}$ moderna, a liberdade individual não está exatamente sobreposta à liberdade política, pública. Constant, ao analisar o ostracismo ${ }^{36}$ de Atenas ("Todo exílio político é um atentado político"), mostra-se mais preocupado com a autoridade arbitrária do governo, daí a sua conclusão:

A liberdade individual, repito, é a verdadeira liberdade moderna. A liberdade política é a sua garantia e é, portanto, indispensável. Mas pedir aos povos de

\footnotetext{
${ }^{34}$ No original: "Il en est de la religion comme des grandes routes: j'aime que l'Etat les entretienne, pourvu qu'il laisse à chacun le droit de préférer les sentiers".

${ }^{35}$ No francês, besoin. Na conferência, a liberdade individual é a necessidade moderna e a liberdade política é sua garantia. Nos Princípios, o direito à liberdade individual é a garantia que o cidadão tem contra as arbitrariedades do poder. Pierre Manent defende que Constant não julga qual época é melhor, justamente porque coloca a comparação nos termos da necessidade. Nós procuramos defender aqui que além das necessidades serem diferentes, há também juízo de valor.

${ }^{36} \mathrm{O}$ ostracismo era a prática do desterro, a que se condenavam em Atenas os cidadãos que por seu mérito ou poderio se tornavam suspeitos.
} 
hoje para sacrificar, como os de antigamente, a totalidade de sua liberdade individual à liberdade política é o meio mais seguro de afastá-los da primeira, com a conseqüência de que, feito isso, a segunda não tardará a lhes ser arrebatada (CONSTANT, antigos e modernos, p. 21).

Portanto, a liberdade política torna-se a garantia da fruição pacífica da independência privada porque é a via de controle que o indivíduo tem sobre a instância política, o meio disponível para observar o governo e não permitir que este seja uma ameaça à sua liberdade individual. Daí a necessidade do sistema representativo. É também o que permite preservar a política. 


\title{
Capítulo 2: os pressupostos do conceito de liberdade
}

\section{I - O problema da soberania do povo}

Nos Princípios de Política encontramos mais elaborada a crítica das teorias dos filósofos do século XVIII. No capítulo intitulado Da soberania do povo, Benjamin Constant assume, num primeiro momento, o princípio rousseauísta da soberania do povo como a supremacia da vontade geral sobre toda vontade particular. O primeiro problema que se impõe a esta definição é que muitos crimes foram feitos sob o pretexto de fazer valer a

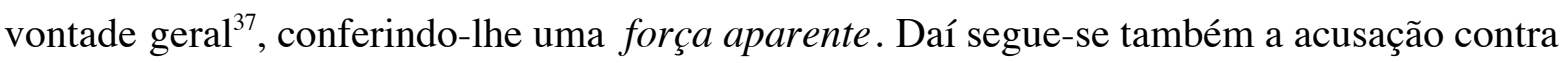
Rousseau: o filósofo que criou a liberdade deu os maiores pretextos à tirania.

O segundo problema está em sustentar a definição apenas na teoria, o que seria correr o risco de fundamentar a lei da vontade geral numa abstração que não leva em consideração a realidade prática da política; caímos, assim, no primeiro erro, isto é, não prever as adversidades circunstanciais possíveis, como foi o caso dos abusos feitos, na Revolução Francesa, em nome da soberania do povo. Assim, tanto um erro quanto outro têm em comum o problema da soberania do povo poder não expressar a vontade de todos, mas apenas de alguns:

\begin{abstract}
A lei deve ser a expressão ou da vontade de todos, ou da vontade de alguns. Ora, qual seria a origem do privilégio exclusivo que você concederia a essa minoria? Se é a força, a força pertence a quem dela se apossa; ela não constitui um direito e, se você a reconhecer como legítima, ela o será igualmente, quaisquer que sejam as mãos que a empunhem, e cada um quererá conquistá-la por sua vez. Se você supuser o poder da minoria sancionado pelo assentimento de todos, esse poder se torna, então, a vontade geral (CONSTANT,2005 $5^{38}$, p.7).
\end{abstract}

\footnotetext{
${ }^{37}$ Refere-se a Robespierre.

${ }^{38}$ A tradução das citações dos Princípios de Política é de Eduardo Brandão, edição da Martins Fontes. "La loi doit être l'expression ou de la volonté de tous, ou celle de quelques-uns. Or quelle serait l'origine du privilège exclusif que vous concéderiez à ce petit nombre? Si c'est la force, la force appartient à qui s'en empare; elle ne
} 
Quaisquer que sejam as mãos que a empunhem, ou seja, qualquer representante, ou qualquer forma de governo: teocracia, realeza, aristocracia também podem ser expressão da vontade geral; caso dominem os espíritos dos indivíduos, são legítimos, quando não dominam, tornam-se apenas a força, e, portanto, um poder ilegítimo. O que nos interessa é pensar as possibilidades das formas legítimas de poder, para que não se corrompam na prática, que são, neste caso, as tocantes à vontade geral e à sua forma correspondente no plano do direito: a soberania do povo.

Portanto, independentemente da forma de governo que se estabeleça - eis um dos princípios do liberalismo de Benjamin Constant - é preciso pensar o que é a soberania do povo e até onde pode ela ir, a fim de que mantenha a legitimidade na vontade geral, livre ${ }^{39} \mathrm{da}$ sua determinação pela forma de representação política, ou seja, a fim de que a teoria não se torne "calamidade na aplicação". O risco que corremos com a abstração da teoria da soberania do povo - de Rousseau, segundo a leitura de Benjamin Constant - é perdermos o grande direito, fundador do próprio conceito: "O reconhecimento abstrato da soberania do povo não aumenta em nada a soma da liberdade dos indivíduos; e se se atribuir a essa soberania uma latitude que ela não deve ter, a liberdade pode ser perdida apesar desse princípio, ou até por causa desse princípio" (CONSTANT, ibidem, p. 8). Desse modo, segundo Constant, se não observarmos a natureza da soberania do povo, podemos não gozar da liberdade individual, e, se não observarmos sua latitude ou extensão, se ultrapassarmos os limites, a liberdade pode ser perdida justamente em nome da própria soberania do povo.

Quando se estabelece que a soberania do povo é ilimitada, cria-se e lança-se ao acaso na sociedade humana um grau de poder demasiado grande por si mesmo e que é um mal, quaisquer que sejam as mãos em que for posto. Confiem-no a um só, a vários, a todos, e encontrarão igualmente um mal.

constitue pas un droit, et si vous la reconnaissez comme légitime, elle l'est également, quelques mains qui s'en saisissent, et chacun voudra la conquérir à son tour. Si vous supposez le pouvoir du petit nombre sanctionée par l'assentiment de tous, ce pouvoir devient alors la volonté générale".

${ }^{39}$ Daí Benjamin Constant ser considerado por muitos como um político mais fiel a sua teoria do que aos partidos que defendem monarquia ou república. Na primeira redação dos Princípios de Política, em 1806, tinha por extensão ao título da obra: "Aplicáveis a todos os governos representativos". Na revisão e publicação dos Princípios de Política em 1815, como Conselheiro do Estado de Napoleão, acrescentou, "e em particular à constituição atual da França". Assim, soube defender a monarquia constitucional, soube defender a república: não importa a forma de governo, o que importa são os princípios que garantam a liberdade. 
Vocês se voltarão contra os depositários desse poder e, conforme as circunstâncias, acusarão sucessivamente a monarquia, a aristocracia, a democracia, os governos mistos, o sistema representativo. Estarão errados: o que se deve acusar é o grau de força, e não os depositários dessa força. É contra a arma e não contra o braço que convém ser severo. Há massas pesadas demais para a mão dos homens (CONSTANT, Idem $^{40}$, p.8).

Assim, o erro está em voltar-se contra as instituições políticas, quando o problema está nos limites do poder. Se ajustarmos os princípios da política, podemos aplicá-los a qualquer forma de governo; garante-se, com isso, a liberdade dos indivíduos. Com esse raciocínio também garante-se o sistema liberal, marcado pela separação da forma de governo da sociedade. Mais ainda, o que está separado aqui é a figura do governante, não se trata mais de pensar que forma de governo nem quem governará, mas as instituições necessárias para garantir a liberdade dos indivíduos. Estrategicamente, como Constant publica essas linhas durante o governo napoleônico ${ }^{41}$, ressalta em diversas passagens que a atual Constituição é a melhor possível. Aliás, foi o próprio Constant, sempre desejoso de ter participação destacada na política, que redigiu o ato adicional da Constituição, a pedido de Napoleão. É uma forma muito curiosa, se não audaciosa, de participar do governo e ainda assim defender seu sistema liberal. Constant acredita de fato que o problema está no grau de poder e não no seu depositário. Não se trata, portanto, de uma adaptação ${ }^{42}$ teórica às circunstâncias práticas.

Vontade geral e soberania do povo estão "emprestados" de Rousseau. Como muito bem observa Todorov, Constant aceita o postulado de Rousseau - o poder deve ser a expressão da vontade geral - mas não aceita que ele seja ilimitado, emprestando, então, de Montesquieu sua idéia de limitação. A vontade geral deve ser moderada, Rousseau não tendo

\footnotetext{
40 "Lorsqu'on établit que la souveranité du peuple est illimitée, on crée et l'on jette au hasard dans la societé humaine un degré de pouvoir trop grand par lui-même, et qui est un mal, en quelques mains qu'on le place. Confiez-le à un seul, à plusiers, à tous, vous le trouverez également um mal. Vous vous em prendrez aux dépositaires de ce pouvoir, et suivant les circonstances, vous accuserez tour à tour la monarchie, l'aristocratie, la démocratie, les gouvernements mixtes, le système représentatif. Vous aurez tort; c'est le degré de force, et non les dépositaires de cette force qu'il faut accuser. C'est contre l'arme et non contre le bras qu'il faut sévir. Il y a des masses trop pesantes pour la main des hommes."

${ }^{41}$ A publicação dos Princípios de política aplicáveis a todos os governos representativos e em particular à atual Constituição da França data de maio de 1815, na ocasião em que Benjamin Constant fora Conselheiro do Estado de Napoleão, durante os Cem-Dias.

${ }^{42}$ Certamente Benjamin Constant fez adaptações às circunstâncias em alguns momentos importantes, ele mesmo fazia questão de explicar os motivos pelos quais alterava o texto a cada nova publicação. Concordam os estudiosos que as alterações não comprometem seus princípios, defendidos do começo ao final de sua vida.
} 
percebido que "a autonomia da coletividade entra em conflito com a autonomia do indivíduo" (TODOROV, 1997, p. 33). Se a soberania do povo não for limitada e se for, além disso, abstrata, dá margem ao despotismo, como foram os anos do Terror. É preciso, então, construir um muro, diz Todorov, que proteja o indivíduo das arbitrariedades do poder, de modo que assegure os dois territórios: público e privado. Isto porque, o indivíduo é irredutível à sua sociedade, os princípios que fundam indivíduo e sociedade não estão em continuidade.

Constant condena Rousseau pela abstração: não percebeu que, na prática, a vontade geral será depositada nas mãos de alguns e que, mesmo legítima (isto é, não se devendo à força, mas ao consentimento), ela torna possíveis todos os abusos contra a liberdade individual. "A universalidade dos cidadãos é o soberano (...) mas daí não decorre que a universalidade dos cidadãos ou os que por ela são investidos da soberania", isto é, os representantes, "possam dispor soberanamente da existência dos indivíduos", porque há uma "parte da existência humana que, necessariamente, permanece individual e independente, e que está de direito fora de qualquer competência social" (CONSTANT, ibidem, p.9). Essa instância é justamente a liberdade individual.

Desse modo, a preservação da liberdade individual está no mesmo registro da Declaração dos Direitos do Homem e do Cidadão, na medida em que ambas - tratadas do ponto de vista do cidadão, do indivíduo - limitam o poder do governante. Ou como afirma Renato Janine Ribeiro:

O súdito é subordinado, o cidadão é ativo. Ora, os direitos humanos consideram o poder do ângulo dos governados, dos de baixo. E protegem essas pessoas dos caprichos e desmandos de quem está em cima, no poder. Entende-se que os direitos humanos, embora acabem sendo um dos grandes traços da democracia moderna, surjam em regimes não-democráticos: seu propósito é limitar o poder do rei, impedi-lo de ser absoluto. Eles expressam a atitude de quem não é cidadão, porém quer reduzir ao mínimo sua sujeição, sua condição de súdito (RIBEIRO, A Democracia, p. 22).

A Declaração dos Direitos do Homem e do Cidadão de 1789 é, nesta medida, uma proposta de formar cidadãos onde havia súditos, ao reduzir a autoridade do poder político 
dos governantes. Portanto, o valor dos direitos do homem em 1789 se dá justamente diante de um governo despótico ou absolutista, e não de um governo democrático ${ }^{43}$. No entanto, a habilidade de Constant está em observar que, como os direitos humanos foram deixados de lado pela Convenção, também o poder irrestrito do povo pode ameaçá-los. Nosso autor retoma, com o conceito de liberdade individual, um aspecto que lhe parecia essencial em 1789: a limitação do poder, pois sem ela Robespierre, Napoleão ou qualquer outro, não importa quem, podem violar os direitos do homem. Eis o que dá a Constant uma posição singular entre defensores e detratores da Revolução, entre amigos e inimigos da liberdade individual. Na contradição entre liberdade individual e soberania do povo, Constant procura conciliá-las. Outros tomarão o partido ora da liberdade individual, como Burke e os conservadores, ora da soberania do povo, como a tradição de esquerda que se firmará no século XIX.

Assim, a soberania precisa ser limitada e relativa, só assim é soberania, de outro modo é ilegítima. Seu limite é a independência individual. "O assentimento da maioria não basta, de modo algum, em todos os casos, para legitimar seus atos", diz Constant em seguida, não importa a fonte do ato: indivíduo, sociedade, ou a nação toda. Mais importante do que monarquia, democracia, república, o que conta para legitimar o poder é sua limitação.

Circulando em torno dos termos do contrato social de Rousseau, Benjamin Constant enuncia as idéias principais do contrato e apresenta uma objeção a cada uma delas: os "atributos preservadores" do contrato social são conferidos ao ser abstrato, que Rousseau chama de soberano, que se compõe de todos os indivíduos. O problema é que quando o soberano precisa usar a força, ele a delega, e, com isso, os atributos preservadores desaparecem. Quando Rousseau diz que "dando-se a todos não se dá a ninguém", Constant diz o contrário, "dá-se aos que agem em nome de todos". Quando se lê no contrato social que "dando-se por inteiro, estão todos iguais", Constant afirma que alguns tiram proveito do sacrifício dos outros, e existem associados que estão fora dessa condição. Também não é verdade, diz Constant, "que todos os associados adquirem os mesmos direitos que cedem: ora,

\footnotetext{
${ }^{43}$ Daí o aspecto curioso dos direitos humanos, que tornaram-se, depois, a essência da democracia: "Assim, um conceito que nasce para impedir que o poder dos reis deslize para o absolutismo ou o despotismo acaba restringindo o próprio poder da assembléia popular. Um conceito que surge como restrição à monarquia termina fazendo parte da essência da democracia" (RIBEIRO, A democracia, p. 23).
} 
nem todos ganham o equivalente do que perdem, e o resultado do que sacrificam é, ou pode ser, o estabelecimento de uma força que lhes tira a que têm" (CONSTANT, ibidem, p. 11). A vontade geral, esse simulacro mentiroso da liberdade, dirá Constant numa nota, na verdade escraviza o indivíduo fazendo-o assinar um pacto de liberdade ${ }^{44}$.

A solução constantiana é a preservação dos direitos individuais, pois uma vez garantidos, nunca se corre o risco de ações ilegítimas, seja da parte que for, arbitrárias, abusivas etc. Este é o limite do poder:

\begin{abstract}
Os cidadãos possuem direitos individuais independentes de toda autoridade social ou política, e toda autoridade que viola esses direitos se torna ilegítima. Os direitos dos cidadãos são a liberdade individual, a liberdade religiosa, a liberdade de opinião, na qual está incluída a sua publicidade, o gozo da propriedade, a garantia contra toda e qualquer arbitrariedade. Nenhuma autoridade pode atentar contra esses direitos sem rasgar seu próprio título (CONSTANT, idem, p. 14).
\end{abstract}

Nota-se, mais uma vez, que Constant quer preservar as conquistas do que ele considera ser a proposta inicial da Revolução Francesa, mostrando que os abusos do poder soberano levam necessariamente à negação da Revolução.

\title{
II - Sistema representativo
}

A representação política é uma invenção moderna, dirá Constant, agradando estrategicamente aos monarquistas, ao demonstrar a inviabilidade da democracia direta. Mas, ao mesmo tempo articula uma crítica à proposta dos ultramonarquistas de não haver mais eleição na França, o que seria um retorno, não à democracia direta dos antigos, mas ao Antigo Regime.

\footnotetext{
${ }^{44}$ É interessante a leitura de Manent sobre o problema da soberania em Constant. De um modo geral, Manent analisa que Constant não faz (e não pode fazer) uma crítica à lógica interna da idéia de soberania, porque essa crítica vai contra o liberalismo. A saída, então, de Constant seria fazer a crítica à imagem que a idéia de soberania representa: a cidade antiga.
} 
O sistema representativo é entendido, na Conferência, como uma organização através da qual cada indivíduo confia a outros "o que não pode ou não quer fazer". Ora, o homem moderno não tem tempo para preocupar-se com os assuntos públicos, mas também não pode deixá-los completamente à deriva, nas mãos de qualquer um, sem fiscalização, pois corre o risco de reunir a força da representação nos braços de um tirano. Se negligenciarmos nossos direitos políticos, corremos o risco do retorno de Napoleão, ou ainda, do cerceamento de nossas liberdades pelo poder dos ultramonarquistas, o risco, enfim, da apatia política dos cidadãos diante da proposta antidemocrática. É com este raciocínio sutil que Constant compara antigos e modernos, na analogia com pobres e ricos:

\footnotetext{
"Os pobres fazem eles mesmos seus negócios; os homens ricos contratam administradores. (...) Mas, salvo se forem insensatos, os homens ricos que têm administradores examinam, com atenção e severidade, se esses administradores cumprem seu dever, se não são negligentes, corruptos ou incapazes." (CONSTANT, antigos e modernos, p.23).
}

Assim, a representação política é uma procuração que a nação precisa dar a alguém porque não tem tempo, ela mesma, de ocupar-se com os negócios públicos, mas precisa vigiar, controlar, avaliar se os representantes estão trabalhando sem abusar dos poderes conferidos. Passar uma procuração não é o mesmo que assinar um cheque em branco, isto é, não significa conferir todo poder, cegamente, ao representante.

Ainda na comparação com o modelo antigo, podemos pensar que o este precisava ter escravos para poder ser livre politicamente, ao passo que o moderno precisa ser representado politicamente para poder ser livre como indivíduo. Ou ainda, como bem explica Hartog:

Ao permitir ao indivíduo não ser um 'escravo' no domínio público, embora não governando diretamente ele próprio, a representação vem bloquear o torniquete da liberdade e da escravidão proposto por Rousseau. Os antigos são livres e escravos: para ser livres, devem ao mesmo tempo ter escravos e ser escravos. Os modernos são livres e representados: para ser livres, devem ser representados. A grande divisão opera-se claramente sobre o princípio representativo. (HARTOG, 2002, p. 170) 
Portanto, a representação, num sentido, separa sociedade e poder político, quando este é delegado, mas ao mesmo tempo os vincula, quando exige o controle, ou melhor, a vigilância. Atribui liberdade ao indivíduo que quer usar seu tempo para seus prazeres pessoais. Mas o que exatamente a sociedade está entregando nas mãos dos seus representantes? Que poder é esse, já que a liberdade do indivíduo está dissociada do político? Ao representante não é mais atribuído o direito absoluto da preservação da vida dos associados; direito esse que Constant rejeita nas suas leituras de Rousseau, pela refutação da idéia de soberania absoluta, pela prática que observou na Revolução. No limite, a questão é: qual o contorno e a tonalidade que a instância política pode configurar na vida do indivíduo? A resposta nos revela o grau do liberalismo de Constant.

O fundo desse problema reside em pensar naquilo que autoriza a ação dos homens diante da soberania do povo. Veremos na próxima parte certo confronto entre a autoridade da história e da natureza. Numa leitura, podemos ver a legitimação dos limites da esfera política autorizados pela história. Se as ações dos indivíduos compõem a marcha da história, e os homens da Revolução mostraram que agir em nome da soberania do povo tendo representantes com o poder absoluto que, justamente em nome da vontade geral abusaram das liberdades dos indivíduos, então, a própria marcha da história, que é a vontade dos indivíduos, revela a necessidade de limitar o poder do representante, isto é, da instância política. No limite, é a supremacia do indivíduo e a subordinação da política. Mas, pensar que a esfera política está subordinada à esfera privada não significa anulá-la, mas simplesmente encontrar seu limite. Como interpreta Pierre Manent:

(...) se o que tinha de ser representado era o que o movimento espontâneo da história trazia para a sociedade, o representante não mais podia reclamar a soberania absoluta: devia colocar-se a serviço do movimento social. O 'historicismo' de Constant teve aqui por objetivo, ou ao menos por resultado, limitar decisivamente o campo legítimo da ação política; se a história é a autoridade, se o lugar 'natural' da ação da história é a sociedade civil, a instância política achava-se numa posição essencialmente subordinada. (MANENT, 1990, p. 130) 
A representação, assim, ocupa o papel de dissociar o poder da sociedade, e é a expressão maior da liberdade política dos modernos. Há, portanto, a proposta de uma articulação entre as duas formas de liberdade, de modo que uma seja o pressuposto que impeça a supremacia arbitrária e a outra carregue consigo a necessidade do sistema representativo. "É preciso aprender a combiná-las" (CONSTANT, antigos e modernos, p. 25) e não confundi-las, pois "os direitos individuais, são a liberdade; os direitos sociais são a garantia" (CONSTANT, ibidem). A participação política torna-se parte integrante e essencial do sistema da liberdade individual. Sistema de liberdade que inclui uma mistura precisamente dosada de participação política e independência privada, responsabilidade pública e desfrute privado dos prazeres.

Isso significa, importante ressaltar, que a liberdade não está excluída ${ }^{45}$ da esfera política. A vida política não precisa ser obrigatória para o indivíduo, mas é preciso que ele encontre as formas possíveis de se relacionar politicamente. É preciso encontrar outra forma de democracia, na qual o indivíduo possa contribuir e participar de acordo com seu desejo sincero, não fervorosamente como os antigos, pois isso não é mais da paixão moderna. Desse modo, é a representação que permite que o indivíduo seja um cidadão, atuando no domínio político e, ao mesmo tempo, é a própria representação que, ao liberar o cidadão da vida política intensa e direta, proporciona a vida individual e privada.

\section{III - História e Natureza}

Constant traz Condorcet à discussão para ponderar que os antigos "não tinham nenhuma noção dos direitos individuais" (CONSTANT, antigos e modernos, p. 12); ou seja, além de tornar a submissão do indivíduo compatível com a liberdade política, retoma a

\footnotetext{
${ }^{45}$ Hannah Arendt coloca a impossibilidade de banir a liberdade do espaço político, a não ser no governo despótico: "Sempre que o mundo artificial não se torna palco para ação e discurso - como ocorre com comunidades governadas despoticamente que os banem para a estreiteza dos lares, impedindo assim o ascenso de uma esfera pública - a liberdade não possui realidade concreta. Sem um âmbito público politicamente assegurado, falta à liberdade o espaço concreto onde aparecer. (...) A liberdade como fato demonstrável e a política coincidem e são relacionadas uma à outra como dois lados da mesma matéria" (ARENDT, $O$ que é liberdade?, p. 195).
} 
"verdade a ser demonstrada"46 sobre a condição humana de um povo conduzir ao desejo de uma forma específica de sistema político. Não há, assim, um sistema político ideal ou perfeito em si mesmo, a política torna-se submetida ao desejo dos homens na história.

A condição humana conduz, portanto, à ação histórica? Qual é a finalidade da ação histórica dos homens? Por que não se sustenta nas leis naturais, conforme as leituras que Constant fez da tradição haviam lhe ensinado? Não se trata mais de supor um estado de natureza hipotético, como fizeram alguns iluministas. De suas leituras, Constant concluíra que pensar num estado de natureza hipotético no qual todos fossem iguais levaria, necessariamente, à soberania absoluta. Além disso, havia diante dos olhos de Benjamin Constant suas conclusões a respeito da ditadura jacobina, fundamentada na idéia da igualdade do povo e da soberania suprema. Ora, excluída a possibilidade do estado de natureza rousseauísta, significa isso que a igualdade não é possível?

O que Constant aprendeu nas suas leituras e da experiência política foi justamente que é possível pensarmos em indivíduos iguais, mas há um movimento dos homens para alcançar esta condição. Ou seja, um representante, como Robespierre, não pode proclamar, legitimando na natureza, de um só golpe, a igualdade dos indivíduos. Ora, a igualdade não é ponto de partida, não está dada de antemão, porque não é autorizada pela natureza humana. Ao contrário, é o movimento dos homens, pela construção histórica, que leva à igualdade, e, portanto, o representante se submete aos indivíduos. É, politicamente, mais uma forma de cercar o poder.

No texto chamado De la perfectibilité de l'espèce humaine, Constant faz sua análise da "natureza humana", separando as sensações propriamente ditas, que são mutáveis e passageiras, das idéias, formadas pela "lembrança" ou "combinação" das sensações, mais duráveis, podendo ser conservadas num "outro mundo", interior, independente do mundo exterior. É justamente da comparação entre sensações e idéias que nasce a noção de perfectibilidade. Se fossemos governados pela sensação, ou seja, pelo desejo da natureza, não poderíamos esperar melhorias, já que seríamos os mesmos desde sempre.

\footnotetext{
46 "C'est à vous démontrer cette vérité que la lecture de ce soir sera consacrée." (CONSTANT, antigos e modernos, p. 593).
} 
Se, ao contrário, o homem governa-se pelas idéias, o aperfeiçoamento está assegurado. Mesmo que nossas idéias atuais fossem falsas, elas portam um germe de combinações sempre novas, de retificações mais ou menos prontas, mas infalíveis, e de progressão não interrompida (Benjamin CONSTANT, $1997^{47}$, p. 704).

Assim, é a razão que pode ser aperfeiçoada, daí todo esforço para consolidar as idéias e não as sensações como o lugar da independência moral e da tranqüilidade da vida. Graças à capacidade da perfectibilidade ${ }^{48}$ interior, o homem caminhou, historicamente, na direção da igualdade, de modo que conseguiu fazer quatro grandes revoluções:

Essas quatro revoluções, a destruição da escravidão teocrática, da escravidão civil, da feudal, da nobreza privilegiada, são outros tantos passos na direção do restabelecimento da igualdade natural. A perfectibilidade da espécie humana não é outra coisa senão a tendência para a igualdade. Essa tendência vem de que somente a igualdade é conforme à verdade, isto é, às relações das coisas entre si e dos homens entre eles (CONSTANT, ibidem $^{49}$, p.714).

A marcha da espécie humana, através da perfectibilidade, se dirige sempre para a igualdade, um progresso necessário e crescente. O que nos interessa nesse momento é seu caráter de irreversibilidade, ou seja, como a perfectibilidade interna é propriamente a moralidade do homem, uma vez mudada de perspectiva, não se pode retroceder. O universo moral e mental, pensa Constant, o modo de pensar e as concepções gerais do que é viver em

\footnotetext{
${ }^{47}$ As citações das Mélanges de Littérature et de Politique são retiradas da edição Folio. Tradução livre. "Si, au contraire, l'homme se gouverne par les ideés, le perfectionnement est assuré. Lors même que nos ideés actuelles seraient fausses, elles portent en elles un germe de combinaisons toujours nouvelles, de rectifications plus ou moins promptes, mais infaillibles, et de progression non interrompue."

48 "Pour la perfectibilité intérieure, c'est-à-dire la morale, nous avons l'abolition de l'esclavage, qui est pour nous une vérité évidente, et qui était le contraire pour Aristote. (...) Telle est la marche de l'esprit humain, que les hommes les plus absurdes d'aujourd'hui ne peuvent, em dépit d'eux, rétrograder au point où en étaient les plus éclairés des siècles antérieurs. Quand le temps et le raisonnement ont fait complètement justice d'une instituition fausse, la sottise même et l'intérêt personnel n'osent plus la réclamer. Pour la perfectibilité extérieure, nous avons une multitude de découvertes: celles de Galilée, de Copernic, de Newton (...) Cette marche de la perfectibilité peut être suspendue, et même l'espèce humaine forcée de rétrograder em apparence; mais elle tend à se replacer au point où elle était, et elle s'y replace aussitôt que la cause matérielle qui l'em avait éloignée vient à cesser" (CONSTANT, 1997, pp. 709- 710).

49 "Ces quatre révolutions, la destruction de l'esclavage théocratique, de l'esclavage civil, de la féodalité, de la noblesse privilégieé, sont autant de pas vers le rétablissement de l'égalité naturelle. La perfectibilité de l'espèce humaine n'est autre chose que la tendence vers l'égalité. Cette tendance vient de ce que l'égalité seule est conforme à la vérité, c'est-à-dire aux rapports des choses entre elles et des hommes entre eux".
} 
sociedade mudam de forma irreversível. A tese da irreversibilidade histórica se sustenta, então, na tendência para a perfectibilidade, que, por sua vez, é o lugar das condições morais que não podem ser recuperadas: "Os antigos estavam em plena juventude da vida moral; nós estamos na maturidade, ou talvez na velhice" (Constant, antigos e modernos). É como tentar reviver a inocência perdida na infância. Por isso, ao comparar os antigos com os modernos, Benjamin Constant sustenta, para além (e por causa) das mudanças nas condições materiais da existência, uma análise psicológica, julgando em cada aspecto, qual é a melhor época.

\begin{abstract}
Pouco importa que tal povoado, em tal época, gozasse de mais felicidade ou possuísse mais luzes que um tal outro povoado, em uma época seguinte, se for demonstrado que a massa dos homens que coexistem num tempo qualquer é sempre mais feliz que a massa dos homens coexistentes num tempo anterior. Não é preciso dizer: os atenienses eram mais livres que nós; então, o gênero humano perde em liberdade. Os atenienses eram uma pequena parte dos habitantes da Grécia; a Grécia, uma pequena parte da Europa, e o resto do mundo era bárbaro, e a imensa maioria dos habitantes da Grécia era composta de escravos. Que nos demonstrem na história uma época semelhante à nossa, tomada no seu todo. A Europa inteira é isenta do flagelo da escravidão; os três quartos dessa parte do globo estão livres do feudalismo, a metade libertada dos privilégios da nobreza" (CONSTANT, $1997^{50}$, p. 712).
\end{abstract}

Benjamin Constant tenta articular duas exigências separadas: crer na humanidade universal, fundada na liberdade, mas, ao mesmo tempo, levar em consideração a evolução da sociedade, pois o homem é um só, seja qual for seu estado evolutivo. Portanto, mesmo se tudo for mutável na sociedade, resta algo de estável. A perspectiva de Todorov mais uma vez focaliza a possibilidade de articulação entre os conceitos: desse modo, a liberdade não se resolve pela escolha de um dos termos em detrimento do outro, mas pela definição dos níveis nos quais eles intervêm.

\footnotetext{
50 "Peu importe que telle peuplade, à telle époque, ait joui de plus de bonheur ou possédé plus de lumières que telle autre peuplade, à une époque suivante, s'il est démontré que la masse des hommes coexistant dans um temps quelconque est toujours plus heureuse que la masse des hommes coexistant dans um temps antérieur. Il ne faut pas dire: les Athéniens étaient plus libres que nous; donc le genre humain perd em liberté. Les Athéniens étaient une petite partie de l'Europe, et le reste du monde était barbare, et l'immense majorité des habitants de la Grèce elle-même était composée d'esclaves. Que l'on nous montre dans l'histoire une époque semblable à la nôtre, prise en grand. L'Europe entière est exempte du fléau de l'esclavage; les trois quarts de cette partie du globe sont affranchis de la féodalité, la moitié délivrée des privilèges de la noblesse".
} 
Já Marcel Gauchet direciona o problema da história em Constant para outro lado, ao ressaltar a importância de romper com o passado, com a noção de contrato original, ao integrar a história como dimensão política. A categoria da mobilidade é o fundamento da separação entre sociedade civil e Estado, pois, ao contrário, tomar o passado para legitimar o presente é prender-se na imobilidade. Conseqüentemente, segundo Gauchet, não temos que olhar para o passado, mas para o devenir, para a igualdade:

Eis o verdadeiro limite da ação do Estado: o vir-a-ser. Na medida em que seu papel é de prescrever, de editar, de determinar, numa palavra, de desejar, o poder é por excelência estacionário. (...). É a sociedade que é propriamente o agente da história, que é progressiva, na medida em que ela é interação permanente de vontades privadas cuja pluralidade e independência liberam inovação quando a instância que quer em nome de todos fixa e determina, mesmo quando ela aspira precipitar o movimento (GAUCHET, $2005^{51}$, pp. 300-301).

A perspectiva de Gauchet se dirige para a idéia de movimento social como o agente limitador do poder, na superação do caráter estático do Estado, que parece oferecer uma resistência à marcha da humanidade. Não se trata, nessa leitura, de combinar as duas instâncias - história e natureza - mas de expor o seu conflito.

Pierre Manent coloca o problema em outros termos. Constant transita entre as duas autoridades distintas, vacila entre uma e outra conforme convém à circunstância política da Revolução Francesa. Mas não há um puro arrivismo seu, pois as oscilações acontecem sempre para o mesmo fim: limitar o poder. É preciso pensar na liberdade fundada na natureza, incondicional e necessária, mas também na marcha em direção da igualdade, relevante papel do movimento social. Por que foi necessário recorrer à autoridade da natureza, na experiência da prática política de Constant?

\footnotetext{
51 "Voilà la vraie limite de l'action de l'Etat: le devenir. Dans la mesure où son rôle est de prescrire, d'edicter, de déterminer, en un mot de vouloir, le pouvoir est par essence stationnaire (...). C'est la société qui est proprement l'agent de l'histoire, qui est progressive, dans la mesure où elle est interaction permanente de volontés privées dont la pluralité et l'indépendance libérent de l'innovation quand l'instance qui veut pour tous fixe et arrête, lors même qu'elle entend précipiter le mouvement."
} 
Mas, dirão alguns, não pode a autoridade da história servir, ao contrário, para justificar o despotismo? O que responder ao governo que declara: "O estágio histórico atingido por nossa sociedade exige que..."? O que responder a Danton quando ele decreta: "Esses padres e esses nobres não são culpados, mas é necessário que morram, pois estão fora do lugar, entravam o movimento das coisas e atrapalham o futuro? (MANENT, 1990, p. 131).

Assim, simultaneamente, a sociedade é agente da história, com mobilidade tal que sua dissociação do Estado lhe permite seguir o caminho do progresso, mas também é determinada pela pluralidade das vontades dos indivíduos particulares, o que significa, em tempos modernos, ser determinada pelo desejo de liberdade individual. Logo, o desejo de liberdade dos modernos não pode ser o mesmo desejo de liberdade dos antigos, o primeiro inscrito no registro civil, o último no registro político, de acordo com o próprio modo de vida das sociedades em seus respectivos estágios do progresso.

O argumento da história é o fundo em que bate a teoria de Constant. Os comentadores que trouxemos aqui - Marcel Gauchet, Pierre Manent e Tzvetan Todorov - não divergem propriamente a respeito de suas leituras sobre Constant, mas acentuam pontos diferentes, o que fica mais claro na concepção de história constantiana. Manent analisa parte da história do liberalismo, de Maquiavel a Tocqueville, a partir da perspectiva do par história e natureza. Foi ele quem nos ajudou a esclarecer que Constant tenta conciliar esse par, mas não sobrepô-lo ou identificá-lo, como faz Guizot, o defensor do liberalismo de governo ${ }^{52}$. Todorov também compreende a teoria de Constant sempre a partir de um par de opostos e de sua tentativa de articulá-lo, mas, no caso do argumento sobre a história, entende que a articulação se dá entre liberdade e determinismo. Rejeitamos essa leitura por pensar que o problema do determinismo não está dado em Constant. Já Gauchet é o único dentre eles que

\footnotetext{
${ }^{52}$ Pierre Manent ressalta que o liberalismo de Constant é "de oposição", essencialmente crítico e negativo, ao passo que o de Guizot é "de governo", estruturante e positivo. "O que deu cor própria ao liberalismo governamental de Guizot foi a reconciliação ou harmonia que ele afirmou ou postulou entre o movimento da história e as características da natureza humana. (...) É que, em Guizot, a autoridade da história era a mesma coisa que a da natureza: o movimento histórico tinha conduzido os povos europeus a viverem no regime representativo, o único que satisfazia todos os requisitos morais e políticos da natureza humana" (MANENT, 1990, p. 149). Para Guizot, também há o problema do anacronismo, mas não tão forte como em Constant. Em 1820 Guizot fora "empurrado" para a oposição, pois não podia concordar com a tentativa dos Ultra monarquistas de voltar ao Antigo Regime. Mas em 1840, com alto cargo no governo, defendeu um liberalismo que aproxima sociedade e Estado.
} 
vê Constant como um grande e autêntico filósofo da história, e conferindo-lhe um papel mais central do que entendemos que tem.

Que peso tem e que lugar ocupa a dupla autoridade, natureza e história, na teoria de Benjamin Constant? Na tradição, vemos, através de Pierre Manent, que Constant participa da construção do liberalismo moderno na Europa. Para não serem opostos é preciso encontrar sua constelação conceitual comum. Por que história e natureza fazem parte da mesma constelação que liberdade e igualdade?

Parte da teoria de Benjamin Constant é fundamentada na história, na perfectibilidade em direção da igualdade. Mas os princípios, como a liberdade, não. Estão fundados na natureza. Constant não podia justificar o Terror na história, Robespierre não podia matar arbitrariamente em nome do momento da Revolução, que exigiria isso, mesmo que buscasse uma forma de legitimar suas ações na soberania do povo. Assim, os princípios precisam ser garantidos atemporalmente, não só independentemente da forma de governo, mas também da marcha da história. A perfectibilidade leva os homens à igualdade, não à liberdade.

Mas, com isso, não defendemos - diferentemente de Manent - que Constant tenha adaptado sua teoria, realizado um ajuste, apenas para fazer funcionar todos os seus argumentos e garantir os princípios. Sugerimos que é a partir da demanda política real que Benjamin Constant edifica o seu liberalismo, com contornos próprios, justamente porque vivenciou um período em que as posições políticas estavam confusas e começavam a ganhar contornos mais nítidos $^{53}$. Foi, portanto, através do diálogo com as situações políticas distintas que Constant foi repensando sua teoria, às vezes mais flexível ou moderado, às vezes um oposicionista mais radical.

\footnotetext{
${ }^{53}$ De acordo com Célia Galvão Quirino, o termo "liberal" designava mais uma posição política do que propriamente uma teoria no início do século XIX. Falava-se em "english libéraux" na Inglaterra e na França o termo aparece através dos "realistas", que durante a Restauração chamam de liberais os seus oponentes, sentados à esquerda na Câmara. Cf. QUIRINO, Célia. Liberdade e igualdade. Revista Discurso, n. 15, 1983.
} 


\section{Capítulo 3: desdobramentos da liberdade moderna - o sistema político e o indivíduo}

\section{I - Liberalismo}

Giramos em torno da questão acerca da natureza do liberalismo de Constant. De acordo com as próprias declarações do autor, seu liberalismo não é aquele que pensa num Estado mínimo, muito menos no Estado como um mal necessário ${ }^{54}$. O liberalismo constantiano é aquele em que mesmo a liberdade do indivíduo não pode ser assegurada sem a intervenção das instituições políticas. Não estamos, desse modo, no registro de um individualismo que pensa a liberdade a partir do seu interior, ou que considera bastar uma mudança ética no indivíduo para que a ordem política o deixe em paz. Constant não exige do indivíduo moderno que mude sua consciência para que haja mudanças nas instituições políticas. Ora, não há individualismo em Constant? Certamente. Só que a sutileza está em pensar que o indivíduo moderno já é outro, distinto do antigo, e suas necessidades, de fato, são privadas. Há um individualismo na medida em que Benjamin Constant constrói uma teoria política que privilegia e mantém a integridade do indivíduo. A preservação do espaço privado do indivíduo é o que fundamenta e legitima a sua teoria política.

É um liberalismo que se edificou como essencialmente crítico, uma proposta de oposição à arbitrariedade do poder. Mais do que isso, Constant elaborou ${ }^{55}$ a teoria do poder

\footnotetext{
${ }^{54}$ Nas Mélanges, Constant deixa isso muito claro, ao refutar a teoria de Godwin: "Ele parte de um princípio falso. O governo, diz Godwin, é um mal necessário. Essa idéia, que não é dele, parece, num primeiro golpe de vista, um pensamento forte, e não é, no fundo, senão uma expressão bizarra" (CONSTANT, 1997, p. 682). Em seguida Constant explica que o governo só pode ser um mal quando sai da sua esfera própria. No entanto, de acordo com a nossa leitura de seus escritos como um todo, pudemos perceber que se trata justamente de um liberalismo com o Estado mínimo.

${ }^{55} \mathrm{Na}$ verdade, o próprio Constant confessa que não criou a teoria do poder neutro. O responsável pela elaboração do conceito teria sido Clermont-Tonnerre, que morreu durante a Revolução. Há também forte influência do sistema constitucional inglês, o qual Benjamin Constant admirava profundamente. Quando analisa o problema da destituição do poder executivo: "A realidade inglesa cria esse poder neutro e intermediário: é o poder real separado do poder executivo. O poder executivo é destituído sem ser perseguido. O rei não precisa convencer seus ministros de uma falta, de um crime ou de um projeto para depô-los; ele os depõe sem os punir. Assim, tudo o que é necessário ocorre sem nada do que é injusto; e, como sempre acontece, esse meio, por ser justo, ainda é útil de outro ponto de vista (...). Os representantes, após a dissolução da sua assembléia, os ministros, após sua destituição, voltam à categoria dos outros cidadãos, e os resultados desses dois grandes defensivos contra esses abusos são igualmente eficazes e pacíficos" (CONSTANT, 1997, p. 24). Ao direito de dissolver as assembléias
} 
real ou neutro ${ }^{56}$, o qual é responsável por equilibrar os outros poderes numa monarquia constitucional, ao manter a independência dos poderes entre si e do povo. Mas tal poder não se faz presente somente em uma monarquia, pois Constant também recomendou, na república, um poder que seja neutro entre o povo e o executivo. $\mathrm{O}$ poder executivo - conferido aos ministros -, o poder legislativo e o judiciário são independentes entre si e ativos, já o monarca detém o poder neutro, capaz de ajustar os outros três poderes quando estes se desregulam. $\mathrm{O}$ poder neutro é uma força externa aos três poderes, que será aplicada para preservá-los e repará-los, sem hostilidade, de modo a garantir que os poderes atuem sempre em colaboração. É um poder intermediário que busca o equilíbrio, posicionado entre os poderes e acima deles, "autoridade ao mesmo tempo superior e intermediária" (CONSTANT, 1997, p. 19). O conceito de poder neutro é parte integrante e essencial da proposta constitucional do nosso autor, seja para monarquia, seja para república. No caso da monarquia, tratado especialmente nos Princípios de Política pela ocasião do governo de Napoleão, Constant ressalta ainda a necessidade dos tribunais nos quais o rei deve proferir qualquer sentença. Sem o concurso dos tribunais, afirma nosso autor, veremos "a violação de todos os princípios, a confusão de todos os poderes (...) e seriam ruins e pérfidos aqueles conselheiros que apresentassem a um monarca constitucional, como objeto de desejo e lástima, essa potência despótica, sem limites, ou melhor, sem freios, que seria equívoco por ser ilimitado, precário por ser violento e que pesaria de maneira igualmente funesta sobre o príncipe, a quem só poderia confundir, e sobre o povo, que ele só sabe atormentar ou corromper" (CONSTANT, 1997, pp. 29-30). Desse

representativas, Constant dedica outro texto, respondendo às críticas feitas tanto ao ato constitucional francês quanto à Constituição da Inglaterra. O principal argumento é a necessidade de limitar a assembléia para que esta não seja tirânica ou ainda, insiste Constant, para que não multiplique demais as leis. O excesso de leis é "a doença dos Estados representativos". É evidente que Constant defende a existência da assembléia representativa, mas defende também que seu limite esteja fora dela.

${ }^{56}$ É bem provável que este poder neutro tenha inspirado a formulação do poder moderador brasileiro. Os comentários sobre a Carta imperial, outorgada em 1824, sempre aludem à influência de Constant sobre os seus redatores. Há, no entanto, uma diferença considerável, pelo menos ao longo do Primeiro Reinado. O poder moderador brasileiro não era separado do executivo. É com Dom Pedro II que, ao se estabelecer um regime parlamentarista, o ministério se distingue do monarca. Mesmo assim, como o "estadista do Império" Nabuco de Araújo disse no Senado, em palavras que ficaram célebres, logo após o Imperador despedir inopinadamente o Gabinete Zacarias de Góis: "O Poder Moderador pode chamar a quem quiser para organizar ministérios; esta pessoa faz a eleição, porque há de fazê-la; esta eleição faz a maioria. Eis aí está o sistema representativo do nosso país!" (Senado do Império, 17 de julho de 1868). 
modo, o poder neutro é a forma constitucional da teoria constantiana para limitar o poder do Estado.

Outro traço marcante do liberalismo de Constant é sua luta pelo sistema eletivo, em oposição ao sistema hereditário. O sistema eletivo é compatível com a igualdade, derruba o esquema dos privilégios do Antigo Regime ${ }^{57}$. A igualdade, como vimos, é autorizada pela história, movida pela perfectibilidade. Ao mesmo tempo, a liberdade não é submetida à autoridade da história, mas antes é um princípio garantido por um direito independente do movimento político que os homens podem construir. Da conjunção desses dois aspectos, formou-se a peculiaridade do liberalismo de Constant, como bem observa Pierre Manent:

O que emprestava cor própria ao liberalismo oposicionista de Constant era a oscilação entre a autoridade da natureza e a da história, entre o indivíduo naturalmente - e, portanto, irredutivelmente - titular de uma esfera de existência e atividade sobre a qual o poder político ou social não podia ter nenhum direito, e o indivíduo como indivíduo moderno, ou seja, necessariamente ligado, em razão do desenvolvimento do "comércio", a seus "prazeres". A resultante dessa oscilação era, na psicologia constantiana, o ceticismo, a divisão interna, a inocência perdida, que invocava a ironia (MANENT, 1990, p. 149).

O liberalismo que se desenvolveu durante e imediatamente após a Revolução foi marcado pela defesa do processo revolucionário, mas não incondicionalmente: os liberais rejeitaram os anos do Terror, considerados abusivos. Posicionaram-se contra qualquer retorno ao Antigo Regime, construíram uma agenda política favorável à representação e à divisão dos poderes, à instância política separada da vida social, ao processo eletivo e, sobretudo, às garantias dos direitos do indivíduo: segurança, liberdade, propriedade e igualdade. No entanto, Constant percebeu que esta pauta política podia degenerar, na realidade efetiva das circunstâncias pós-revolucionárias, em despotismo e no confisco da liberdade individual. Daí outro aspecto particular de seu liberalismo: a combinação da liberdade individual com a participação política, esta última, distinta da liberdade política antiga, como vimos. Em outras palavras, o problema que Constant tentou solucionar foi o seguinte: como e em que medida a

\footnotetext{
${ }^{57}$ Embora Constant tenha dado valor à monarquia francesa e inglesa, não concorda com o sistema aristocrático de privilégios, ou ainda, prefere a liberdade burguesa à liberdade aristocrática.
} 
participação poderia se emancipar da versão antiga da liberdade para adequar-se à forma moderna?

Talvez essa seja a marca mais autêntica do liberalismo constantiano. O liberalismo pós-constantiano colaborou para banir a noção de liberdade do domínio político, na medida em que a política deveria ocupar-se somente da manutenção da vida e dos interesses do indivíduo. A participação ativa de todos os cidadãos na política tornou-se idéia perigosa, pois a imposição da igualdade "aqui e agora", como fizeram tragicamente os jacobinos, paradoxalmente terminava por destruir a liberdade dos indivíduos. Trata-se de repensar o par igualdade e liberdade. Se os contratualistas uniram esse par na autoridade da natureza, os revolucionários não sabiam mais o que fazer com as contradições reais que apareciam na tentativa de efetivar as duas coisas ao mesmo tempo. Enunciar que os homens nascem livres $e$ iguais tornou-se diferente de fazê-los livres e iguais. Se, num primeiro momento, os homens são todos cidadãos e iguais, a liberdade individual - do ponto de vista liberal - já está comprometida. Vemos uma massa uniforme que se sente obrigada a comportar-se segundo um padrão único estabelecido, e essa situação é propícia para desenvolver a tirania ${ }^{58}$. Entretanto, vimos que Benjamin Constant não condena a igualdade nem a opõe à liberdade, também, não estão para ele a liberdade e a igualdade unidas pela condição natural, como quiseram alguns iluministas, mas separadas por autoridades diferentes, de modo que a liberdade é uma exigência presente e incondicional e a igualdade está no campo do vir-a-ser. Será uma conquista da história feita pela ação dos homens livres. Essa é a possibilidade democrática do liberalismo de Benjamin Constant.

É bem verdade que o caráter democrático de Constant é no mínimo controverso. Ele defendeu que os não-proprietários não teriam direitos políticos. Os direitos políticos, para sermos exatos, consistem em: "ser membro das diversas autoridades nacionais, ser membro das autoridades locais dos departamentos e concorrer para a eleição dessas diversas autoridades" (CONSTANT, 2005, p. 281). Explica-se essa tese anti-democrática, justamente porque desigual, pela condição da autonomia ou independência do indivíduo que, se não tiver propriedade, não terá discernimento necessário para agir de acordo com os interesses da

\footnotetext{
${ }^{58}$ Em sua versão mais perigosa, que é o despotismo não de um só, mas o da massa - que pode, porém, culminar no de um só: Napoleão.
} 
nação. Qualquer sistema político, afirma Constant, restringe os direitos políticos. Mesmo a democracia mais absoluta nega aos estrangeiros e aos menores de idade o exercício da cidadania. "É necessária portanto uma condição além do nascimento e da idade prescrita pela lei. Essa condição é o tempo indispensável à aquisição das luzes, à retidão do juízo. Somente a propriedade proporciona esse tempo; somente a propriedade torna os homens capazes do exercício dos direitos políticos" (CONSTANT, 2005, p. 282). O que Benjamin Constant entende por proprietários? Ele esclarece esse ponto numa nota:

Em meus Princípios de Política eu havia sustentado a opinião de só conceder os direitos de cidadania aos proprietários fundiários, mas a experiência me esclareceu. Vi que em nosso século a propriedade industrial era uma propriedade mais real ainda e, principalmente, mais poderosa que a do solo, e, reconhecendo meu erro, corrigi minha obra (CONSTANT, ibidem, p. 282).

Mesmo incluindo os proprietários industriais, a tese de Constant não deixa de soar conservadora ao leitor de nossos dias. O grande problema em conceder direito de cidadania aos não-proprietários, no final das contas, é que eles usariam dos meios políticos para conquistar a propriedade, mas sem trabalhar. Nas suas palavras:

\begin{abstract}
Observe que a finalidade necessária dos não-proprietários é obter a propriedade. Todos os meios que você lhes der, eles empregarão com esse fim. Se, à liberdade de faculdades e de indústria que lhes deve, somarem-se os direitos políticos que não se lhes deve, esses direitos nas mãos do maior número servirão infalivelmente para invadir a propriedade. Eles caminharão por essa via irregular, em vez de seguir a via natural: o trabalho. Será para eles uma fonte de corrupção e para o Estado uma fonte de desordens (CONSTANT, ibidem, p.283).
\end{abstract}

Parece, porém, que Constant defende ao mesmo tempo o direito à propriedade e o direito de propriedade. É o direito inclusive dos não-proprietários a adquirir propriedade, levando, no futuro, a uma expansão do eleitorado que elimine na prática a exclusão dos atuais não-proprietários. Mas é também o direito dos atuais proprietários de manter sua propriedade 
contra tentativas externas de obtê-la por meios ilícitos ou violentos. Assim, se Constant radicalizasse o direito à propriedade, admitiria meios não convencionais de aquisição da propriedade, isto é, meios revolucionários, como o confisco ${ }^{59}$ dos bens ou uma reforma agrária.

Outro desdobramento dessa tese é que Constant ainda acrescenta no final: "São, portanto, necessárias condições de propriedade; elas também são necessárias para os eleitores e para os elegíveis" (CONSTANT, Ibidem, p. 285). Ou seja, os direitos políticos, o exercício da cidadania se aplica também aos eleitores.

Pensando a partir do que lemos em Constant, podemos sugerir a seguinte questão: quem é o cidadão que tem direito às liberdades, afinal? Ou ainda, de modo inverso: a liberdade é para quem? Não é para todos ${ }^{60}$, certamente. Alguns são cidadãos (proprietários e com direitos políticos) e outros podem vir a ser cidadãos. Assim como os menores de idade serão cidadãos ao atingir a maioridade, e com isso, adquirir as luzes necessárias para exercer os direitos políticos, assim também o estrangeiro poderá tornar-se residente e adquirir os mesmos direitos, porque passará a ter interesses comuns com os outros. Melhor dizendo, está no horizonte a distinção que será usual no século XIX entre cidadãos ativos, os proprietários, que têm racionalidade porque têm interesses fixos, que eles podem "bem entender", e os cidadãos passivos, os não proprietários, que têm direitos civis - são protegidos pela lei - mas não os políticos.

A igualdade pode ser conquistada no futuro, lentamente. É a propriedade que determina, então, a cidadania. Por isso, é preciso que a riqueza dos indivíduos aumente para que a faixa da "igualdade" possa também aumentar. Essa tarefa está lançada nas mãos dos cidadãos proprietários. É da responsabilidade dos homens conduzirem a sua história para esse fim. Não é tarefa da política. É uma combinação da perfectibilidade dos homens, capacidade de aperfeiçoamento que conduz à igualdade, e da liberdade do comércio, isto é, da possibilidade de adquirir riquezas e propriedades. Ora, cidadão é apenas o burguês. Só ao burguês são concedidos os direitos políticos; assim também a liberdade individual é a

\footnotetext{
${ }^{59}$ Como propunha Saint Just.

${ }^{60} \mathrm{Ou}$ melhor, em teoria, a liberdade individual é para todos e a liberdade política só pode ser para aqueles que têm condições (materiais, de espírito, de interesse, etc.).
} 
liberdade para o burguês, uma vez que as duas estão, na teoria do nosso autor, conciliadas. No entanto, a exclusão dos não-proprietários não é radical porque é provisória. Mas, se a universalização da propriedade não ocorrer pela via econômica, não ocorrerá a universalização da cidadania, pois não é da ordem da política, para o liberalismo constantiano, assegurar as condições de riqueza necessárias à formação da burguesia.

Outro desdobramento da teoria liberal constantiana é a concepção de indivíduo. O liberalismo, mesmo pré-revolucionário, esforçou-se para separar o Estado e a sociedade. Talvez possamos dizer que o liberalismo revolucionário e o subseqüente aproveitaram essa cisão e criaram um terceiro elemento ${ }^{61}$ : o indivíduo, além do Estado e da sociedade, os três separados e independentes. Este indivíduo ganha, com a Revolução, uma universalidade, expressa nos direitos, e com Constant a dupla autorização: o movimento da história, que o conduz à igualdade, e o princípio da liberdade, na natureza. Também adquire, com nosso autor, traços psicológicos modernos, mas que em nada complementam sua teoria liberal, como veremos no seu romance Adolfo. Não se trata de afirmar que Benjamin Constant criou o indivíduo, mas que se viu na tarefa de atribuir contornos diferentes ao indivíduo que em parte ele tomou emprestado da herança liberal, em parte ele diagnosticou em seu presente. $\mathrm{O}$ indivíduo da tradição liberal já se colocava em oposição à ordem política - assim fizeram os contratualistas. Mas esse indivíduo não podia ser negado em função da ordem política, pela soberania do povo. Por isso Manent define assim: "Constant repetiu, para preservar a liberdade, o primeiro momento, o momento negativo do liberalismo original, e o voltou contra seu segundo momento, o momento positivo ou construtivo" (MANENT, 1990, p. 142). O momento "positivo" do indivíduo liberal é denunciado por Constant como anacrônico, como vimos.

\footnotetext{
${ }^{61}$ Pierre Manent nos traz a idéia do terceiro elemento, mas para ele não é um indivíduo. O indivíduo que os liberais criaram, para ele, é uma abstração. O terceiro elemento é uma instância também chamada de sociedade, distinta da sociedade civil. O que caracteriza esta sociedade nascente no liberalismo é sua autoridade no movimento histórico, não na natureza. É um elemento metapolítico que, no século XIX, veio a determinar a política em sua forma religiosa, até mesmo porque a concepção de história é teleológica.
} 


\section{II - Indivíduo moderno}

Difícil tarefa encontrarmos a identidade do indivíduo moderno. Constant coloca a independência individual como uma necessidade moderna, em oposição à necessidade dos antigos pela liberdade política. Desse modo, tentamos mostrar quais são os critérios usados pelo autor para bem julgar as duas liberdades e suas épocas. Sabemos que o indivíduo não pode ser confundido com a sociedade, não pode ser reduzido a ela. "A liberdade não é outra coisa senão aquilo que o indivíduo tem o direito de fazer e a sociedade não tem o direito de impedir" ou: "Essa liberdade, de fato, é o objetivo de toda associação humana. Ela se apóia na moral pública e privada; sobre ela repousam os cálculos da indústria, sem ela não há para os homens nem paz nem dignidade nem felicidade" (CONSTANT, 2005, p. 153). Dos direitos individuais dos cidadãos, Constant enuncia e desenvolve especificamente os seguintes: liberdade pessoal, liberdade religiosa, liberdade de opinião, garantia contra o arbítrio e gozo da propriedade. Depois acrescenta a liberdade de indústria, isto é, a atividade de produção com livre concorrência.

Assim, vimos que Constant é um partidário da modernidade. Para identificar a época dos indivíduos, traça um quadro comparativo com a época antiga. Vimos esta comparação na Conferência, mas é o mesmo raciocínio que perpassa toda a sua obra. A evolução que chegou até a modernidade é, deste ponto de vista, positiva: mais vantagens e menos inconvenientes. É uma época superior no plano dos valores. A política precisa acompanhar essa evolução, o que nem sempre ocorre.

Em De l'esprit de conquête, a comparação com o passado se dá, sobretudo, pelo caráter belicista. Quando Constant escreve esse texto são os tempos de guerra do império napoleônico. A época moderna é conforme a paz. Não tiramos prazer na guerra como os antigos. Preferimos o repouso, a naturalidade: "O fim único das nações modernas é o repouso, com o repouso, a comodidade, e como fonte de comodidade, a indústria" (CONSTANT, $1997^{62}$, p. 131). Mas, sobretudo, não desejamos guerrear porque não nos é mais útil. "Nosso século, que aprecia tudo pela utilidade, e que, desde que vemos sair dessa esfera, opõe a

\footnotetext{
${ }^{62} \mathrm{~A}$ tradução de L'esprit de Conquête é livre. "Le but unique des nation modernes, c'est le repos, avec le repos l'aisance, et comme source de l'aisance, l'industrie."
} 
ironia ao entusiasmo real ou fictício, não consentiria em alimentar-se de uma glória estéril, não está mais nos nossos hábitos preferir a todas as outras" (itálicos nossos). O que nos interessa? "No lugar dessa glória, seria preciso colocar o prazer; no lugar do triunfo, a pilhagem" (CONSTANT, ibidem ${ }^{63}$, p. 133). Assim, se fizermos guerras na modernidade, nossa meta não será obter glórias e triunfos, mas saquear outro povo.

Encontramos, desse modo, simplesmente outro indivíduo, transformando-se ao longo da história, acrescentados alguns elogios aos tempos modernos, contrários à arbitrariedade do poder, à guerra e à alienação dos direitos do indivíduo. Mas quais os inconvenientes da modernidade? Pois quando Constant faz suas comparações, nem sempre vemos as vantagens do lado moderno.

Ora, podemos considerar que o indivíduo é o mesmo quando atua no espaço público e no privado? Se estas esferas são separadas em Constant, precisamos pensar em dois indivíduos também distintos. Em que medida? Tratamos de pensar até agora nas garantias dessa separação, cabe então pensarmos também no estatuto do indivíduo privado. São os mesmos princípios que regulam a vida política e a particular? Nas suas Mélanges, Constant faz uma crítica a Godwin, especificamente sobre a parte moral da sua idéia de justiça. Podemos transportar a noção de justiça do âmbito social para o íntimo?

\begin{abstract}
Não é sufocando os afetos mais doces que daremos felicidade à espécie humana. Não é preciso que o homem seja sempre imparcial e justo; é preciso o contrário, e é o maior privilégio de sua independência individual que ele seja parcial por gosto, por piedade, por arrebatamento. Magistrado, juiz, homem público, seu dever, sem dúvida, é a justiça; mas a mais preciosa parte de sua existência privada, sobre a qual a sociedade não deve ter nenhum império, é de cercar-se de seres à parte, seres queridos, semelhantes por excelência, distintos de todos os seres de sua espécie. Quando se trata dos outros, basta não nutri-los e alguma vez servir; mas ao círculo favorito, a esse círculo do amor, de emoções, de lembranças, pertencem sua dedicação,
\end{abstract}

\footnotetext{
63 "Notre siècle, qui apprécie tout par l'utilité, et qui, lorsqu'on veut le sortir de cette sphère, oppose l'ironie à l'enthousiasme réel ou factice, ne consentirait pas à se repaître d'une gloire stérile, qu'il n'est plus dans nos habitudes de préférer à toutes les autres". (...) "À la place de cette gloire, il faudrait mettre le plaisir; à la place du triomphe, le pillage." Constant refere-se às guerras napoleônicas, as quais opõe-se claramente. Mas, além disso, seu argumento está baseado no anacronismo das paixões, ou seja, se os modernos fazem guerras, não encontrarão a glória e o triunfo, mas apenas o prazer e a pilhagem. Napoleão pode até tentar convercer os franceses que a guerra é pela liberdade, contudo, a verdade das guerras napoleônicas não é a glória dos antigos, por mais que o Império retome certa mitologia romana: é a conquista de bens materiais, a anexação de territórios.
} 
sua ocupação constante, e todos os gêneros de parcialidade (CONSTANT, 1997, pp. 681-682).

Podemos, então, ser injustos na vida privada? Não é bem isso, diria Constant. Não podemos nos guiar pela mesma lógica, há uma outra lógica que governa nossa existência individual. Através da política, Constant nos mostra que não temos mais aquela paixão antiga pela vida política: ficamos ridículos na praça pública. De acordo com Pierre Manent, é esse desvelamento da insinceridade das paixões modernas que confere o brilho da teoria constantiana.

[O homem moderno] pode, sim, encher-se de orgulho, arrebatar-se, e até se convencer de que acredita na pátria e na virtude, mas após o instante em que se olhar como crente, sente-se ridículo e torna a cair na dúvida. O mais original e o mais precioso da análise constantiana da Revolução e do Império residem nesse desvelamento da inevitável insinceridade das paixões modernas. Essa insinceridade explica, ao mesmo tempo, o caráter extremamente cruel do despotismo da Convenção e sua impotência última (...) (MANENT, 1990, p. 137).

As paixões modernas transbordam das páginas políticas de Constant e encontram uma expressão muito particular num de seus romances: Adolfo. Talvez na literatura Constant não tenha tratado propriamente do desvelamento da insinceridade da paixão moderna, mas fez aparecer um problema bem parecido: a autenticidade do amor e o seu revés, a artificialidade. Segue o conflito insolúvel entre convenção social e espontaneidade do coração. Tanto Eleonora quanto Adolfo sabem que o seu amor já morreu, mas isso não pode ser dito. Quando é dito, pelas cartas que não deveriam ser lidas, rompe-se a lógica da incomunicabilidade dos pensamentos que não podem ser compartilhados na vida social.

É o reverso da medalha. De fato, Constant é escaldado pela experiência do Terror e do Império, de modo que a época moderna não poderia ser, aos seus olhos, o ponto máximo da experiência política, da marcha da igualdade. Mas em que isso afeta o indivíduo? Que Constant faça críticas aos modernos, do ponto de vista da política, é evidente. Ora, e esse indivíduo nascente, ao qual se pretende dar todas as garantias e proteções, que princípios o 
regulam? Ou, em termos mais constantianos: o que ganhamos com a supremacia da vida privada? Uma vida inteira dedicada aos prazeres pessoais é, para Constant, cair na inação.

Vimos na Conferência que, em alguns termos psicológicos da comparação entre antigos e modernos, levam a pior os modernos. Temos menos entusiasmo, somos mais moles, temos uma convicção frouxa e hipócrita sobre as coisas, somos cansados. Constant estaria vacilando ou tentando mostrar o reverso da medalha?

Em algumas poucas passagens podemos encontrar o traço que completa o quadro do diagnóstico da modernidade. Trata-se mais de contrabalançar do que propriamente condenar os tempos modernos. Os resultados das aquisições de nossa civilização podem ser "aflitivos" e "perigosos". Não é crime algum buscarmos a tranqüilidade e o prazer, diz Constant, mas como há, atualmente, facilidade em encontrar a fruição, então é de se esperar que o homem moderno resista a arriscar a posição adquirida. Se é fácil ter prazer, não posso ficar sem ele. Daí a resistência em perder essa posição, mesmo quando algo obriga o abandono do prazer. Quais as conseqüências disso?

Conseqüentemente, esse estado de civilização tende à estabilidade, e, se quisermos, à boa ordem, mais que à virtude moral. Ora, a boa ordem, coisa útil, coisa indispensável aos progressos e à prosperidade das sociedades, é antes um meio que um fim. Se, para mantê-la, sacrificamos todas as emoções generosas, reduzimos os homens a um estado pouco diferente daquele de certos animais industriais, cujas colméias bem ordenadas e as casas artisticamente construídas não seriam contudo o bom ideal da espécie humana (CONSTANT, $1997^{64}$, p. 659).

Não queremos abrir mão dos prazeres nem em nome da boa ordem. Jamais seremos trabalhadores mecanizados. No entanto, é preciso cuidar, diz Constant, para que se preserve a civilização dos perigos que ela pode produzir, pelo resultado da preservação absoluta, sem abrir mão de nada, e ao mesmo tempo, radicalmente oposto, pelos resultados possíveis da

\footnotetext{
${ }^{64}$ "En conséquence, cet état de civilisation tend à la stabilité, et, si l'on veut, au bon ordre plus qu'à la vertu morale. Or, le bon ordre, chose utile, chose indispensable aux progrès et à la prospérité des sociétés, est plutôt un moyen qu'un but. Si, pour le maintenir, on sacrifie toutes les émotions généreuses, on réduit les homes à un état peu different de celui de certains animaux industrieux, dont les ruches bien ordonées et les cases artistement construites ne sauraient pourtant être le beau ideal de l'espèce humaine."
} 
ausência de emoções desinteressadas: o risco da redução da espécie humana à espécie animal. É este o diagnóstico dos últimos anos de sua vida, diante do movimento pós-revolucionário. O que é próprio ao moderno é a reflexão incessante sobre tudo, e isto, invariavelmente, torna-o um homem dividido, porque sempre pondera, avalia, diferente do homem antigo, mais dado à ação.

Se o homem moderno está essencialmente dividido entre sua independência e sua dependência, entre si e si mesmo, pelo olhar de outrem e por sua própria introspecção, se vive, portanto, por intermédio da representação; o mundo da ação política pura, pela qual cada uma se projetaria tal como fosse, ingênua e generosamente, na praça pública, fica-lhe doravante inacessível (MANENT, 1990, p. 137).

A divisão interna a esse indivíduo moderno torna-se, com as palavras de Manent, prazer doloroso e enfermidade salutar. A contradição do indivíduo é alimentada pela divisão entre sociedade e instância política, mediada pela noção de representação política. O homem moderno relaciona-se com a política pela reflexão, diz Benjamin Constant, ao passo que o antigo o faz pela ação, sem mediações.

De acordo com Todorov, é justamente desse embate entre a liberdade dos antigos e dos modernos que nasce a idéia moderna do indivíduo em Benjamin Constant, que chega a nomear os tempos modernos como época dos indivíduos, destacando a relação entre o indivíduo e a sociedade como um combate.

Dos dois pólos da comparação - antigos e modernos - vemos que a crítica não pesa sempre para o mesmo lado. Constant retoma a comparação com os antigos tanto para mostrar que a liberdade é um princípio durável - embora seja solicitada em termos diferentes de acordo com a época - quanto para elogiar e criticar algo dos modernos. Ele não deixa de marcar as fraquezas modernas, mas rejeita a solução de Rousseau e Mably, qual seja reclamar um retorno às categorias antigas em tempos modernos. Sua proposta para resolver as críticas está nos Princípios de Política, nas garantias necessárias para a preservação da liberdade individual. Entretanto, isso não é suficiente. Constant preocupa-se com a liberdade individual 
conjugada à participação política. Sabe dos riscos que o individualismo corre no plano político: "À força de apenas preocupar-se com seus prazeres pessoais, o indivíduo se desinteressa dos negócios públicos e procura ignorar o infortúnio dos outros, esquecendo que seu próprio bem estar privado depende do bem estar público" (CONSTANT, 2005, Additions). Parece-nos que Constant não está somente preocupado com os abusos do poder de Napoleão, mas também com um recuo do cidadão que deserta da praça pública. Ele nos alerta para as conseqüências possíveis (ou necessárias?) do isolamento dos indivíduos sujeitos à arbitrariedade de qualquer poder sem, contudo, renunciar à identidade moderna: é preciso ser um crítico da modernidade, mas, sobretudo, continuar moderno. De acordo com Todorov, Constant não nos coloca em posição de escolha entre a liberdade dos antigos e a dos modernos, mas nos desafia a pensar na articulação possível entre as duas formas de liberdade:

Essas não são as opções a tomar, mas as antinomias que definem o pensamento do homem e das sociedades. A atitude de Constant não é dogmática, mas dialógica, ela não procura fechar o debate por uma resposta simples e definitiva, mas abalar as certezas iniciais para nos conduzir para as convicções mais esclarecidas (TODOROV, 1997, p. 67).

Talvez esteja nessa proposta de articulação a originalidade de Benjamin Constant. Proposta importante tanto para o contexto político - flutuante entre o cerceamento da liberdade individual, do início da Revolução até a Restauração, e a negligente participação política pós-revolucionária - quanto para a história do liberalismo.

Combate e articulação. Dois movimentos que parecem inscritos no campo da democracia. O combate se dá entre o indivíduo e a opressão da sociedade, a articulação é entre a liberdade do indivíduo e a liberdade política. Nas conturbadas relações entre o indivíduo e a ordem política, o autor flutua entre críticas e elogios à modernidade. Deste conflito tentamos entender qual é a identidade do indivíduo moderno que Constant parece construir ou detectar.

O indivíduo protegido pela liberdade e suas garantias é independente da sociedade e salvaguardado do poder arbitrário. O único risco que corre é o de não interessar-se pelos 
assuntos públicos, não controlar seus representantes, o que poderia ameaçar a liberdade individual. Mas não parece, na teoria política de Constant, que o culto ao indivíduo possa pender para o isolamento, pelo cultivo de uma vida vazia, retraída em si a ponto de tornar-se egoísta. É verdade que no seu romance Adolfo aparece o tema do isolamento, mas as circunstâncias são diferentes, trata-se do indivíduo psicológico, fora das suas relações políticas.

Constant, em seus Princípios de Política, também não nos alerta para os perigos do homem confundido com a multidão - embora tenha mencionado o anonimato do homem moderno ao compará-lo com o antigo - nem no campo individual propriamente, nem nas conseqüências políticas. Podemos, contudo, inferir, a partir das suas críticas ao Contrato Social de Rousseau, que alienar a vontade ao soberano é alienar-se de si mesmo, pois Constant pensa que este termo do Contrato, na realidade, faz com que alguns tenham poder e outros não. De qualquer modo, poderíamos concluir que, em Constant, a partir da noção de soberania do povo, o indivíduo perde sua identidade. Afinal, como se dá essa relação de articulação e combate?

A liberdade política é a garantia da liberdade individual porque é o meio para prevenir contra a arbitrariedade do poder. Não há outra importância em conquistarmos a liberdade política, pois ela apenas serve como escudo protetor do indivíduo. Aliás, toda a ordem política se dá em função do indivíduo: a representação, a soberania do povo, as formas políticas. Podemos, então, afirmar que a ordem social e política defendida por nosso autor é o meio para atingir a finalidade da satisfação do indivíduo? Certamente, em Benjamin Constant, não podemos considerar o contrário, ou seja, os indivíduos não podem ser meros meios, dispostos ao sacrifício pelo bem coletivo. Esse raciocínio estaria mais próximo do modelo antigo, embora os indivíduos gregos não sacrificassem, exatamente, sua vida privada, porque o estreitamento da independência não era, segundo Constant, um sofrimento para eles. De qualquer modo, podemos interpretar que Constant entende o modelo antigo como uma relação de supremacia do social, ao passo que o modelo moderno confere a supremacia ao indivíduo. Trata-se de uma questão de meios versus fins? 
Em Constant, os indivíduos são tanto condição quanto finalidade da organização da vida coletiva: "Dar aos depositários da autoridade executiva o poder de atentar contra a liberdade individual significa aniquilar todas as garantias, que são a condição primária e a finalidade única da união dos homens sob o império das leis" (CONSTANT, 2005, p. 157). Dessa forma, entre indivíduo e sociedade não há uma relação de meios e fins, ou seja, a sociedade não é exatamente um meio para levar ao bem-estar do indivíduo. Portanto, a proposta de articulação entre liberdade individual e política não passa pelo ajuste entre meios e fins, mas, antes, fundamenta-se no problema da natureza e da história, como coloca Manent:

\begin{abstract}
Como atribuir os direitos ao indivíduo enquanto tal, uma vez que o direito rege as relações entre diversos indivíduos, uma vez que a própria idéia do direito pressupõe uma comunidade ou uma sociedade já instituída? Como fundamentar a legitimidade política nos direitos do indivíduo, se este nunca existe como tal, se em sua existência social e política está ele sempre necessariamente ligado a outros indivíduos, a uma família, uma classe, uma profissão, uma naçã̃o? (MANENT, 1990, p.9).
\end{abstract}

A questão de Manent revela um dos princípios do liberalismo (ou liberalismo pósrevolucionário), que acentua o ponto de partida - o indivíduo - como uma categoria que, na instância do direito, é apolítica ou associal, ou seja, o indivíduo se comporta como isolado quando está na esfera política. Como Benjamin Constant resolveria essa questão?

Nas suas Mélanges de Littérature et de Politique, encontramos uma polêmica com Bentham e seus colaboradores, sobre o princípio da utilidade. Segundo Constant, os britânicos propõem trocar a noção de liberdade pela utilidade, pois a primeira nos perde de nós mesmos, ao passo que a segunda é mais simples e inteligível. Nesta discussão, o inglês se refere à violação dos direitos inalienáveis propostos pelo franco-suíço. Constant responde a ele na seguinte passagem:

Que grande absurdo, exclama o engenhoso e sábio colaborador de Bentham, direitos inalienáveis que foram sempre alienados, direitos imprescritíveis que sempre prescreveram! Mas, dizendo que esses direitos são inalienáveis e imprescritíveis, afirma-se simplesmente que eles não devem ser alienados, 
que eles não devem ser prescritos; dizemos o que deve ser, não o que é (CONSTANT, $1997^{65}$, p. 667).

Assim, o direito à liberdade está no plano da história porque é da ordem do devir, e não por uma constatação do que de fato ele é, fundado no direito natural, muito menos no estado de natureza isolado. Pensar em direitos naturais e inalienáveis não significa comprometer-se com o jusnaturalismo, como acusa Bentham, mas antes circunscrevê-los na naturalidade do progresso histórico. Daí podermos repensar a questão de Pierre Manent sobre um suposto paradoxo do indivíduo enquanto tal e do direito regulador das relações entre os indivíduos. O direito à liberdade individual, em Constant, tem sua função justamente porque há um conflito entre as novas necessidades do indivíduo moderno (autonomia) e sua vida pública, seja com os outros indivíduos em sociedade, seja na ordem política. De fato, o liberalismo de Constant opera no registro da disjunção entre o poder e o direito, mas isso não significa que o indivíduo é tomado como um ser imaginário isolado, por natureza, dos outros. É preciso, inclusive, a intervenção do direito na liberdade política e na representação para que haja liberdade do indivíduo.

O indivíduo moderno nascente na época ${ }^{66}$, segundo a leitura de Lefort, está comprometido com o domínio de seu destino, mas ao mesmo tempo é despojado da segurança de sua identidade, pois no Antigo Regime, a identidade do indivíduo parecia conferir o seu lugar, sua condição na sociedade. Agora, o indivíduo se descobre sem definição, sem contornos, sem conteúdo e sem objetivo. Talvez isso possa valer mais para a teoria de Tocqueville, sobre a qual Lefort mais se debruça, ainda que preocupado em compará-la com a de Constant. Neste último, não vemos um indivíduo muito convicto, é verdade. Mas ele tem uma clareza: quer a tranqüilidade da vida privada, quer poder deleitar-se com seus prazeres. Há uma identidade em estado nascente, daí sermos inclinados a concordar com Lefort sobre o esvaziamento de conteúdo e objetivo. Vejamos a conclusão de Lefort:

\footnotetext{
65 "Quoi de plus absurde, s'écrie l'ingénieux et savant collaborateur de Bentham, que des droits inaliénables qui ont toujours été aliénés, des droits imprescriptibles qui ont toujours été prescrits! Mais en disant que ces droits sont inaliénables et imprescriptibles, on dit simplement qu'ils ne doivent pas être aliénés, qu'ils ne doivent pas être prescrits; on parle de ce qui doit être, non de ce qui est".

${ }^{66} \mathrm{Na}$ época de Constant e Tocqueville.
} 
O anonimato é o mal absoluto? Isso é afirmado quando se pretende fazer do indivíduo ou da comunidade, ou de ambos a um só tempo, Sujeitos em ato. Mas se se quiser precisamente convir que o indivíduo se furta a si mesmo relacionando-se consigo mesmo, que se defronta com o que é nele(a) desconhecido, por que negar o laço entre solidão e anonimato; por que negar que o reconhecimento do semelhante pelo semelhante também passa pela ignorância aceita do outro; por que, por fim, contrapor, quando se deveria pensar juntas, a verdade da associação e a verdade do isolamento? (LEFORT, 1991, p. 215, grifos nossos).

Ora, não é exatamente essa a proposta de Constant? Articulação entre a liberdade do indivíduo e a liberdade política, preservando a vida privada, o isolamento e, ao mesmo tempo, garantindo a associação pela representação do poder. É bem verdade que, numa leitura, Constant nos faz ver apenas o conflito, de fato existente, entre indivíduo e sociedade, entre indivíduo e poder político. Concordamos que há muito mais ênfase e preocupação com a verdade do isolamento do que com a verdade da associação. Também é verdade que Constant distingue este par. Sua proposta de articulação não ganhou tanto relevo quanto sua contraposição entre antigos e modernos. Não podemos nem ignorá-la, o que faria de Constant um liberal individualista radical, nem podemos atribuir-lhe lugar e valor que não tem, o que faria de Constant um liberal democrata, ou como pensa Todorov a respeito da teoria de Constant: "O melhor regime não é nem a democracia, nem o liberalismo, é a democracia liberal " (TODOROV, 1997, p. 33).

O que ponderamos aqui é que talvez Lefort tenha ignorado a dimensão crítica de Constant em relação ao indivíduo moderno e a importância que nosso autor atribui à participação política e aos laços sociais. Já Todorov talvez tenha conferido a Benjamin Constant um valor maior do que tem: não podemos concordar com toda a dimensão democrática que lhe atribui, pois a participação política, afinal, não tem a mesma dimensão da liberdade individual. Um se engana pela falta e o outro pelo excesso.

O paradoxo se instala, assim, na necessidade de conciliar duas instâncias que parecem separadas desde seu nascimento - ou desde que Constant analisa a teoria de Rousseau - representadas pela relação entre o indivíduo e a sociedade. O Contrato Social exige a integração absoluta do indivíduo no coletivo, mas também pressupõe a existência anterior de indivíduos independentes que pactuam deliberada e igualmente. 


\title{
III - Adolfo
}

Abordemos a construção da personagem Adolfo de Constant. Se não pudermos precisamente considerar Adolfo como a ilustração do homem moderno, podemos ao menos encontrar nele elementos para desvendar a análise psicológica que compõe o estatuto do indivíduo. Vimos que, se o homem antigo tinha um desejo sincero pela política, o moderno já se percebe com um desejo nada sincero, sem verdade alguma, sobre os assuntos públicos. $\mathrm{O}$ homem moderno não tem mais aquele desejo ardente de deliberar na praça pública, sente-se desconfortável e ridículo, não quer ser tolo e muito menos parecê-lo, perdeu o entusiasmo pelos assuntos públicos e sabe disso, daí sua conviç̧ão frouxa e oscilante sobre a política. Na literatura de Benjamin Constant , a marca da paixão moderna será outra. O desejo segue outra lógica, a vida íntima tem exigências e demandas que atingem a si própria, ao ser amado e a sociedade.

Em Adolfo vemos o conflito estabelecido pelo desejo de independência. Este conflito não se inscreve no mesmo registro da liberdade-independência que Constant defende no plano político. De acordo com Todorov é preciso separar os escritos literários e íntimos dos políticos, em certo sentido:

\begin{abstract}
Não é preciso tomar a carta de declarações que semeiam os escritos literários ou íntimos de Constant, nos quais se lê uma demanda de independência definitiva. A liberdade do indivíduo em relação às suas afecções não será pensada segundo o modelo da liberdade do cidadão em relação ao Estado: a independência afetiva não equivale à autonomia política. A independência não é senão um momento no jogo do desejo-falta: onde o sujeito não tem mais nada a desejar e procura escapar do aborrecimento (TODOROV, 1997, p. 124).
\end{abstract}

Ou seja, a noção de independência não pode ser tratada fora de seu contexto, é sempre relativa ao objeto que quer separar-se, do qual se almeja a independência. No romance, Adolfo atribui valor à independência quando está com Eleonora; mas com o fim da relação, a independência perde o valor. $\mathrm{Na}$ análise de Todorov, a independência representa o 
"deserto do mundo", a liberdade é o "isolamento" e a "falta de amor" (TODOROV, ibidem, p. 125).

Outro motivo pelo qual não podemos identificar as paixões políticas com as morais é a distinção das funções da linguagem em Constant. "Há uma linguagem que designa o mundo, que pode ser verdadeira ou falsa, usada nos escritos políticos; e outra que se comunica ao indivíduo para produzir certo efeito, que pode ser medida em termos de bem e mal" (TODOROV, Ibidem, pp. 138-139). Levando em consideração que um romance não pode ser refutado, ao passo que uma teoria política precisa ser examinada pelas lentes da validade, a teoria da linguagem em Constant pode sobrepor-se aos conteúdos propriamente ditos?

Por ocasião da segunda edição do romance, Benjamin Constant escreve um prefácio intitulado Ensaio sobre o caráter e o efeito moral da obra. $\mathrm{O}$ autor pretende rebater os comentários que foram tecidos sobre a relação entre o romance e sua vida pessoal, "conjecturas absurdas", declara nosso autor, que não foram feitas pela sociedade, mas por "homens que, rejeitados pelo mundo, observam-no de fora com uma curiosidade inepta (gauche) e uma vaidade ferida, e buscam encontrar ou causar um escândalo numa esfera acima deles" (CONSTANT, 1992, p. 7). Não se trata, portanto, de uma obra de confissão. No entanto, o próprio Constant, no mesmo prefácio, compara seu romance ao de Chateaubriand (René) e com os de Mme. de Staël (Corinna e Delphina), justamente na tentativa de provar que as quatro obras são apenas ficções, e que "procurar alusões em um romance é preferir o incômodo (tracasserie) ao fluir natural, e privilegiar a bisbilhotice (commérage) à observação do coração humano" (CONSTANT, ibidem, p. 8). Desse modo, esses romances podem ser pensados como "adaptações mais ou menos livres", moldadas na experiência pessoal.

O romance de Constant ocupa, em toda a sua obra, o lugar da análise, da penetração no Eu pela sensibilidade romântica: uma vida instável, a dificuldade de agir frente à realidade, a sensação de insatisfação permanente, as perturbações do coração, as confusões das paixões, as angústias de toda ordem e o conflito entre o indivíduo e a sociedade. Mas essas características presentes em Adolfo não revelam sua singularidade. Stendhal refere-se a 
Adolfo como "uma declaração de ódio"67, muito mais que uma declaração de amor, pois sua originalidade consiste em dissecar a deterioração da relação entre Adolfo e Eleonora.

A deterioração da relação do casal é um tema marcante no romance, trata-se da degeneração do laço amoroso. Contudo, Benjamin Constant adverte ainda no segundo prefácio que sua intenção principal não é demonstrar os perigos das ligações amorosas:

\begin{abstract}
Não quis somente provar o perigo dessas ligações irregulares que, comumente, mais encarceram quanto mais livres faz com que nos imaginemos. Esta demonstração teria tido sua utilidade, mas não era, todavia, minha idéia principal. Independentemente das ligações estabelecidas que a sociedade tolera e condena, há, no simples costume de se empregar a linguagem do amor e de se oferecer a si mesmo e a outrem emoções passageiras, um perigo que jamais foi, até aqui, suficientemente apreciado. $\mathrm{O}$ homem envereda por uma estrada cujo termo não saberia prever, desconhece o que inspirará e o que se expõe a sentir. Divertindo-se, produz consequiências cuja força não calcula, nem a reação sobre si mesmo; a ferida que parece aflorar pode ser incurável (CONSTANT, 1992, Prefácio, p. 9).
\end{abstract}

Há, certamente, o tema das ligações amorosas transformado no jogo da liberdade e da prisão, da conquista e da falta, como veremos mais adiante. Assim como há a forte presença do conflito entre a sociedade e o indivíduo. Mas o que Benjamin Constant ressalta aqui é o caráter trágico da ação humana, ou ainda o que Stendhal afirma a esse respeito: un marivaudage tragique ${ }^{68}$. A linguagem do amor, em Adolfo, é essencialmente trágica na medida em que faz com que a personagem aja através de emoções efêmeras que resultam em feridas incuráveis, sem essa intenção, isto é, sem calcular que provocará tais insatisfações.

Adolfo se apresenta como um rapaz de vinte e dois anos recém-formado na Universidade de Göttingen onde a dedicação e o êxito nos estudos geraram uma expectativa falsa em seu pai ("fizeram crescer em meu pai esperanças provavelmente muito exageradas a meu respeito", p. 21). Apresenta-se, sobretudo, como um rapaz tímido, assim como seu pai. É uma timidez que entrava sua tomada de decisão e de escolha; é um freio em sua liberdade:

\footnotetext{
${ }^{67}$ Citado na edição Flammarion do romance Adolphe de Constant, por Daniel Leuwers, no apêndice, p. 217.

${ }^{68}$ Marivaudage é uma referência ao estilo de afetação de Marivaux, escritor do século XVIII. Assim como Marivaux, Adolfo não tem dificuldade em declarar seu amor a Eleonora. Sua dificuldade está justamente em declarar seu ódio. Cf. Adolphe, edição Flammarion, p.217.
} 
Eu ainda não sabia o que era a timidez, esse sofrimento interior que nos acompanha até a idade mais avançada, recalca em nosso coração as impressões mais profundas, gela nossa fala, desnatura em plena boca tudo o que tentamos dizer e não nos permite expressar-nos senão por palavras vagas ou por uma ironia mais ou menos amarga, como se tentássemos nos vingar, em nossos próprios sentimentos, da dor que experimentamos em não poder dá-los a conhecer (CONSTANT, 1992, p. 22).

A timidez é um constrangimento que Adolfo sofre, assim como seu pai. A consequiência desse caráter é fechar-se em si mesmo e considerar os outros como obstáculos. "A sociedade me incomoda, a solidão me oprime" (CONSTANT, Ibidem, p. 48). Adolfo carrega o incômodo dessa duplicidade. Por um lado, a sociedade é um fardo: "Acostumei-me a guardar dentro de mim mesmo tudo o que sentia, a elaborar apenas planos solitários e a só contar comigo mesmo para a sua execução, a julgar as advertências, o interesse, a ajuda e até mesmo a presença alheia como um incômodo, um obstáculo. (...) daí também um desejo ardente de independência, uma enorme impaciência com os laços que me cercavam e um invencível terror de me ver cercado por novos". Por outro lado, a solidão oprime: "Ao não interessar-me por nada além de mim, interessava-me bem pouco por mim mesmo" (CONSTANT, 1992, p. 23), a solidão esvazia e o deixa na inação.

Assim, ampliando a análise, do ponto de vista psicológico, pode-se ver tanto na esfera pública o limite da liberdade de Adolfo quanto na esfera privada o reflexo do esvaziamento desse indivíduo. A esfera pública é o lugar das convenções, dos preconceitos, preceitos comuns, fórmulas dogmáticas, enfim, da opinião pública que julga moralmente, condena, e determina a pena. "A sociedade é por demais poderosa, reproduz-se sob muitas formas, impõe amarguras demais ao amor que não tenha sancionado" (CONSTANT, 1992, p. 130). Responsável pelas infelicidades do casal, a sociedade julgou tanto Eleonora quanto Adolfo, punindo este último "por suas qualidades mais ainda que por seus defeitos, porque suas qualidades nasciam de suas emoções e não de seus princípios" (CONSTANT, ibidem, p. 131). A vida em sociedade traz esse peso. O que poderia ter feito para aliviar ou remediar? Como proteger o indivíduo dessa sociedade hipócrita? Essas questões nos enviam, novamente, ao indivíduo e à liberdade moderna. Não sugerimos que a liberdade moderna 
possa ser o antídoto para os males que a sociedade causa ao indivíduo, mas, antes, que essa questão é perseguida também no romance de Constant.

No romance, o autor explora o mal-estar desse homem, sempre dividido entre seus valores e as crenças sociais, um homem que adquire a consciência do que há de falso, fútil e superficial em si mesmo. Adolfo também se sente, ao mesmo tempo, dividido entre o desejo por Eleonora e a necessidade de ficar sozinho. Tais cisões do coração formam "um retrato bastante real da miséria do coração humano"(CONSTANT, 1992, p. 133), quer dizer, do homem que busca servir à sua própria paixão, desdobrando o seu amor numa espécie de egoísmo e, por outro lado, dedicando-se apaixonadamente a uma mulher quando há obstáculos para conquistá-la; vencidos os obstáculos, não a deseja mais. Assim, seu amor é egoísta, mas não está a serviço do seu interesse, mas da sua paixão. Além disso, se Adolfo é uma "declaração de ódio", ainda nos resta a questão: não há amor ou é Adolfo que não sabe amar?

\begin{abstract}
Havia contraído de minhas conversas com a mulher que primeiro desenvolvera-me as idéias, uma insuperável aversão por todos os preceitos comuns, por todas as fórmulas dogmáticas. Bastava-me ouvir a mediocridade dissertar satisfeita sobre princípios bem estabelecidos, moralmente incontestáveis, sobre conveniências ou religião, coisas que nivela com visível gosto, para sentir-me impelido a contradizê-la, não por haver adotado opiniõ̃es opostas, mas por impacientar-me uma convicção tão firme, tão grosseira. Não sei que instinto advertia-me de resto para desconfiar destes axiomas gerais tão isentos de qualquer restrição, tão despidos de qualquer nuance. Os tolos fazem de sua moral uma compacta e indivisível massa, de modo a se verem o menos possível por ela perpassados em suas ações, deixadas livres em todos os detalhes (CONSTANT, 1992, p. 26).
\end{abstract}

Adolfo sabe que não pode escapar nem de uma coisa nem de outra. Vive nessa oscilação, busca seu espaço no convívio social e a fruição de seus prazeres privados e, sem encontrá-los, sempre desconfortável, convive com essa duplicidade, como mostra na metáfora do salão de espetáculo, do homem que, entrando na platéia, sufocado pela multidão, procura um lugar para sentir-se confortável: 
(...) é necessário tempo para habituar-se à espécie humana tal como a fizeram o interesse, a afetação, a vaidade e o medo. $\mathrm{O}$ espanto da mocidade, face a uma sociedade tão artificial e elaborada, anuncia antes um coração natural do que um espírito daninho. De resto, nada há a temer nessa sociedade. Tanto pesa sobre nós, tão poderosa é sua surda influência, que não tarda a modelar-nos conforme o molde universal. Nada mais nos surpreende senão nossa antiga surpresa e sentimo-nos bem sob nossa nova forma, assim como respira-se livremente em uma platéia lotada pela multidão, enquanto ao penetrar-lhe respirava-se com esforço (CONSTANT, 1992, p. 27).

Adolfo não suporta carregar este peso, sente-se esmagado pela responsabilidade de abandonar as crenças pessoais, que agora não se identificam mais com as adversidades que o relacionamento com Eleonora impõe. Quando Eleonora rompe com o marido e decide viver com Adolfo, seu desejo por ela já havia se esvaído ${ }^{69}$. Desespera-se porque não tem coragem de desvelar, num primeiro instante, a si mesmo, e depois para ela e para a sociedade, que não a ama. Neste momento, seu pai envia-lhe uma carta afirmando que não concorda com o relacionamento dos dois, mas que está disposto a ajudá-lo no que for preciso. No final da carta está escrito:

Subvencionarei com liberalidade tuas despesas. Sentirás tu mesmo, e bem cedo, que a vida que levas não é a que te convinha. Teu nascimento, teus dons e tua fortuna te assinalam um outro lugar no mundo, não o de companheiro de uma mulher sem pátria e aventureira. (...) Consomes inutilmente os melhores anos de tua juventude, e essa perda não se repara (CONSTANT, Ibidem, p. 77).

Finalmente Adolfo poderia se sentir livre do seu tormento e ainda amparado pelo pai que, ao mostrar rejeição por Eleonora, faz Adolfo tomar mais consciência do seu desejo de

\footnotetext{
${ }^{69}$ Quando Eleonora se entrega a Adolfo, ele já começa a tratar o amor de forma ambigua, como podemos ver na seguinte passagem: "Enfim, entregou-se a mim por inteiro. Infeliz o homem que, nos primeiros momentos de uma relação amorosa, não acredita que ela deva ser eterna! Infeliz aquele que, nos braços da amada recémconquistada, conserva uma funesta presciência e prevê que dela poderá separar-se! Uma mulher arrebatada pelo coração possui nesse instante algo de comovente e sagrado. Não é o prazer que corrompe, nem a natureza ou os sentidos, mas os cálculos a que a sociedade nos habitua e as reflexões advindas da experiência. Eu amava e respeitava Eleonora mil vezes mais agora que se havia entregue. Caminhava orgulhoso em meio aos homens, fazia deslizar sobre eles um olhar dominador. $\mathrm{O}$ ar que respirava era por si só uma fruição. Lançava-me ao encontro da natureza para agradecer-lhe o bem inesperado, o imenso bem que havia se dignado a me conceder" (CONSTANT, ibidem, p. 51). Embora Adolfo tenha consciência que amava Eleonora "mil vezes mais", chamanos a atenção para o "infeliz" que não acredita no amor eterno.
} 
conquistar independência. O problema é que Adolfo é movido por obstáculos. Seu pai não lhe impôs nenhum, ao contrário, abriu todos os caminhos para sustentar a sua liberdade. Daí a conclusão de Adolfo: "Mas não havia mais perigos: davam-me total liberdade, e esta liberdade não me servia senão para carregar com mais impaciência o fardo que aparentemente escolhera" (CONSTANT, 1992, p. 78). Portanto, quando finalmente pode ser livre, independente, não sabe o que fazer, não sabe aproveitar.

A aposta de Adolfo é aparentemente no amor. Em que circunstâncias ele começa a se interessar por Eleonora, uma mulher casada, dez anos mais velha e estrangeira? Quando um amigo lhe confessa seu amor por uma mulher, Adolfo sente despertar nele o interesse por fazer o mesmo. "O espetáculo de uma tal felicidade me fez lamentar o fato de jamais havê-la experimentado; jamais tivera até então uma ligação feminina que pudesse adular meu amor próprio" (CONSTANT, ibidem, p. 29). Ou seja, o desejo de apaixonar-se nasce em Adolfo antes de conhecer Eleonora, somente porque ele percebe que nunca se sentira amado; esse artifício criou nele uma nova necessidade. Assim que ele nota esse novo fato em seu coração, Adolfo nos relata a concepção que seu pai tem sobre as mulheres e sobre o casamento. É uma concepção praticamente aristocrática, que Adolfo define como um "sistema bastante imoral". Do ponto de vista de seu pai, as relações amorosas são divertimentos e só o casamento deve ser tratado com seriedade, contanto que não se cometa a loucura de "comprometer-se de modo durável com alguém que não o iguale perfeitamente em fortuna, nascimento e vantagens exteriores" (CONSTANT, ibidem, p. 30). Isso também significa que Adolfo já sabia, de antemão, que o casamento com Eleonora seria reprovado por seu pai. Quando Adolfo vê Eleonora pela primeira vez, na casa de seu marido, o Conde $\mathrm{P}^{*}$ (uma família aliada à sua), descreve-a como uma mulher essencialmente infeliz. "Oferta a meus olhares num momento em que meu coração necessitava de amor, minha vaidade de sucesso, Eleonora pareceu-me uma conquista digna de mim" (CONSTANT, ibidem, p. 34). Segue-se a partir desse momento a perseguição incansável de Adolfo para conquistar Eleonora. Importante notar que desde o início do interesse de Adolfo até o seu fim todas as ações e inclusive os sentimentos são acompanhadas pelo cálculo, embora calcular as ações não signifique controlá-las. Adolfo observa as situações com distanciamento, frieza e imparcialidade, pois sabe que seu interesse 
por ela tem como causa a satisfação do amor próprio, "esse amor próprio era um terceiro entre mim e Eleonora" (CONSTANT, ibidem, p. 35). Adolfo passa a ter consciência de que não a ama, mas quer amá-la, quer agradá-la para despertar o desejo que satisfaça seu amor próprio ${ }^{70}$. Pensa em todas as formas possíveis de conquistá-la e esse raciocínio o fazia distanciar-se do sentimento: "Quase sempre, para estarmos bem interiormente, travestimos nossa impotência e nossa fraqueza em cálculos e sistemas: isto satisfaz uma porção de nós que é, por assim dizer, espectadora da outra" (CONSTANT, Ibidem, p. 36). Assim, o que poderia ser uma aposta no amor torna-se, na verdade, raciocínio e cálculo para alimentar a vaidade. E ele sabe que coloca o cálculo no lugar do amor: "Não é o prazer que corrompe, nem a natureza ou os sentidos, mas os cálculos a que a sociedade nos habitua e as reflexões advindas da experiência" (CONSTANT, Ibidem, p. 51). Adolfo não ama nem Eleonora, nem o amor. Ele coloca entre si mesmo e o sentimento uma distância, uma névoa, uma zona em que reina o cálculo, uma negociação com o padrão moral imposto pela sociedade. Adolfo revela os valores românticos da sociedade, os quais é preciso combater, porque são empecilhos para o amor burguês.

Há uma definição de amor no romance que traz à tona a implicação da casualidade, pois rejeita uma concepção de amor eterno, ao exprimir a necessidade de marcar na temporalidade o sentimento que está apenas conforme às leis elementares.

O amor supre a falta de lembranças por uma espécie de mágica. Todas as outras afeições necessitam de um passado: o amor cria, como por encanto, um passado de que nos cerca. Dá-nos, por assim dizer, a consciência de havermos vivido anos a fio com alguém que há pouco era quase um estranho. O amor é só um ponto luminoso, e, contudo, parece apoderar-se do

\footnotetext{
${ }^{70}$ Ou melhor, não é simplesmente vaidade, porque ele se sente mal quando vê que ela o ama. Trata-se mais de piedade do que de amor, Adolfo não consegue mais abandoná-la por piedade a ela, não para nutrir seu amor próprio. De qualquer modo, é um amor sem densidade, pálido, como na seguinte imagem: "(...) com ela, por vezes, retomava a linguagem do amor; mas tais emoções e tal linguagem pareciam essas folhas pálidas e sem cor que, fúnebre vegetar, crescem languidamente sobre os ramos de uma árvore abatida" (CONSTANT, 1992, p. 86). Poderíamos comparar esta imagem dos ramos com aquela que fará Stendhal. Neste, a cristalização dos galhos representa a doçura daquilo que permanece na relação amorosa, já em Adolfo são folhas pálidas e sem cor, não há memórias que se cristalizam, como no Amor de Stendhal. Embora possamos dizer que para ambos Constant e Stendhal - a paixão não é algo que vem do fundo do coração (como seria para o romantismo de Rousseau) mas que pode ser produzida.
} 
tempo. Há poucos dias não existia, logo mais, deixará de existir: mas enquanto existe esparge sua claridade sobre o tempo precedente e sobre o tempo que o sucederá (CONSTANT, 1992, p. 47).

A recusa do amor eterno é um elemento que compõe a personagem de Adolfo. Já Eleonora parece encarnar justamente a necessidade do amor eterno - esse, um elemento do conflito entre os dois. Quando Adolfo pensava amá-la, estava iludido, depois, quando nota que, pelo contrário, não a amava, ao finalmente poder viver com ela sem impedimentos, iludiu-a: "sem dizer jamais o bastante para satisfazê-la, dizia sempre o suficiente para iludi-la" (CONSTANT, Ibidem, p. 70). No entanto, afirmar que o amor de Adolfo seja temporário não implica que ele não seja capaz de sofrer. Ao contrário. Adolfo sofre quando se sente apaixonado por Eleonora, mas igualmente sofre quando percebe que não a ama mais; sofre quando decide abandoná-la e voltar para a casa do pai, sofre quando decide voltar para ela e dar-lhe todo o apoio que pede; no limite, sofre quando está com ela, sentindo-se preso; sofre depois que ela morre, sentindo-se livre demais. Na verdade, sempre sofre. Seus sentimentos só o fazem sofrer.

Esses aspectos inscrevem Adolfo no seu tempo? Segundo um de seus tradutores, o príncipe Wiazemsky: "Todos os seus traços, bons ou maus, são absolutamente contemporâneos. Ele se apaixona, ele seduziu, ele se cansou, ele sofreu e atormentou, ele foi vítima e tirano, ele deu prova de recusa e de egoísmo e de uma maneira desconhecida anteriormente, enquanto a sociedade foi revestida de um tipo de egoísmo coletivo e solidário no qual vieram a se fundar os egoísmos particulares" (Wiazemsky, apud Léon, Constant, p. $68)$.

Além disso, o que caracteriza a humanidade moderna é o traço cosmopolita e sem fronteiras. Essa discussão perpassa a obra com muita sutileza. Eleonora é polonesa, descrita pelo pai de Adolfo como "uma mulher sem pátria e aventureira", vivendo na França. O romance começa na Itália, na viagem em que conhece o autor da história que será contada. Aliás, este homem, um viajante pelas aldeias da Itália, um estrangeiro na Calábria, diz: "Estar aqui ou ali me é indiferente" (CONSTANT, 1992, p. 17). Constant refere-se a este homem, 
portador $^{71}$ da história de Adolfo, como um estrangeiro. A história teria sido publicada na

Alemanha, por incentivo de uns amigos. Esse estrangeiro é Adolfo que, embora francês, é um homem sem pátria que ama uma mulher polonesa, também sem pátria. Justamente por esses detalhes, o tradutor classifica a obra como cosmopolita:

Esses ensaios não são provocados absolutamente sobre uma obra exclusivamente francesa, mas sobretudo européia, sobre uma representação que não é absolutamente da sociedade francesa, mas de seu século, da metafísica mundana, por assim dizer, prática da nossa geração...Os marcos que separam, no vale, as línguas, as leis e os costumes, não atingem essa região superior. Nela todas as individualidades se nivelam, todas as diversidades se fundam. Adolfo não é nem francês, nem alemão, nem inglês, é um aluno do seu século (Wiazemsky apud Léon, ibidem, p. 68).

Assim, o que é particular à sociedade está ultrapassado pelo tempo: o indivíduo moderno é um cidadão do mundo. O romance transborda essa dupla aparência: sem data, sem pátria, mas também é fechado no indivíduo.

Em Adolfo vemos, especificamente, ser traçada a figura do indivíduo na sua instância moral. Nas palavras de Constant, num prefácio abandonado para o romance:

Eu quis pintar em Adolfo uma das principais doenças morais do nosso século, esta fadiga, esta inquietude, esta ausência de força, esta análise perpétua, que coloca uma segunda intenção por trás dos sentimentos e que tira o brilho de seus nascimentos. Nós não sabemos mais amar, nem crer nem querer. Cada um duvida do que diz, sorri da veemência do que afirma, e pressente o fim do que experimenta. Resulta daí que o Céu não oferece mais nenhum refúgio ${ }^{72}$.

\footnotetext{
${ }^{71}$ Sugerimos que este recurso narrativo é usado para conferir distanciamento e veracidade à história. O romance é narrado em primeira pessoa, mas é apresentado por outro narrador que não sabemos quem é. Esse narrador decide editar a história dez anos depois de encontrá-la, por acaso.

72 "J'ai voulu peindre dans Adolphe une des principales maladies morales de notre siècle, cette fatigue, cette inquiétude, cette absence de force, cette analyse perpétuelle, qui place une arrière-pensée à côté de tous des sentiments, et qui par là les flétrit dès leus naissance. Nous ne savons plus aimer, ni croire, ni vouloir. Chacun doute de ce qu'il dit, sourit de la véhémence de ce qu'il affirme, et pressent la fin de ce qu'il éprouve. /.../ Il en résulte que le Ciel n'offre plus de refuge". CONSTANT, projeto abandonado para o prefácio de Adolfo, apud: TODOROV, pp. 50-51.
} 
Adolfo explora, portanto, o mal-estar do homem moderno, por perceber-se como um homem dividido, no limite, entre os princípios da sociedade e os princípios que regem o indivíduo, ou ainda, entre os valores, afetos e as leis. Para Constant, a sociedade e o indivíduo dissociam-se por princípios, por isso um não pode ser reduzido ao outro.

Todorov aponta para uma proposta de fusão fracassada, no romance. Em Adolfo, haveria um ideal de fusão, que está relacionado à lógica do desejo. O coração de Adolfo fica insatisfeito com o amor de Eleonora, mas fica inquieto e melancólico quando perde esse amor $^{73}$. O amor é, sobretudo, uma falta. Quando o coração está preenchido com o que deseja, sente-se cansado, quando se liberta do peso, arrepende-se do que não tem. Daí a expressão colocada no final do romance: a "miséria do coração humano". O coração é miserável porque guiado apenas pelos interesses individuais, é o amor egoísta, embora não haja interesse de Adolfo em levar alguma vantagem sobre Eleonora ("Eu me encolhera, por assim dizer, em um novo gênero de egoísmo, um egoísmo sem coragem, insatisfeito e humilhado", p. 95). O paradoxo se dá, na verdade, porque o objetivo da relação amorosa é a falta. Adolfo deseja a solidão, mas quando fica só, é um tormento, assim como a vida conjugal. Por isso que a fusão entre dois indivíduos pelo amor é apenas ideal, já que o desejo é pela ausência. Adolfo entrega todo seu amor a Eleonora ("Vês que dispões de toda a minha existência"), mas apenas em palavras. É um homem do cálculo, da análise, das palavras. Já ela entrega-se visceralmente a este amor, expresso na terrível frase proferida antes de sua morte: "Desejei o que não era possível. O amor era toda a minha vida: não podia ser a tua" (CONSTANT, 1992, p. 120). Esta fusão, além de impossível, é a causa das infelicidades dos dois. Quando a fusão não se completa, Adolfo estaria livre para voltar ao círculo social, submeter-se aos preceitos da sociedade. Por outro lado, isso não faria sentido, pois ele luta a vida toda contra a sociedade, mas também não encontra a felicidade quando se liberta do amor de Eleonora. Ele se cansa da presença porque sua relação com ela é apenas um contato, não é uma relação autêntica. Muita coisa não pode ser dita a ela, então Adolfo escreve cartas aos outros para dizer o que não pode ser dito: "Ele teria podido contrair laços mais honrosos, dizia a opinião

\footnotetext{
73 "O exemplo de Adolfo não será menos instrutivo, se acrescentares que, após haver repelido o ser que o amava, não tonou-se menos inquieto, menos agitado, menos insatisfeito; que não fez uso algum de sua liberdade reconquistada ao preço de tantas dores e tantas lágrimas; e que, tornando-se digno de reprovação, tornou-se também digno de piedade" (CONSTANT, 1992, p. 130).
} 
comum: ele não o dissera a ela, não o dissera talvez a si próprio; todavia, o que não se diz nem por isso deixa de existir e tudo o que é se adivinha" (CONSTANT, Ibidem, p. 50). No prefácio à segunda edição, Constant esclarece:

\begin{abstract}
Algumas pessoas me inquiriram sobre o que Adolfo deveria ter feito para causar e padecer menos dores. Para sua posição e a de Eleonora não havia saída e é precisamente o que eu desejei. Mostrei-o atormentado, porque pouco amava Eleonora; mas não teria sido menos atormentado se a amasse mais. Sofria por ela, à falta de sentimento: com um sentimento mais apaixonado, teria sofrido por ela. A sociedade, desaprovadora e desdenhosa, teria vertido todo o seu veneno sobre a paixão que seu consentimento não houvesse sancionado. Não começar tais ligações é o que se precisa para uma vida feliz: uma vez que se tenha tomado esta estrada não se tem mais escolha entre o mal e o mal (CONSTANT, 1992, pp. 11-12).
\end{abstract}

Desse modo, a escolha do amor coloca-se diante de uma aporia, o sofrimento é inerente à paixão moderna. A sociedade é um dos obstáculos que impede o amor, a não ser que Adolfo tivesse seguido os conselhos do pai, porta-voz dos preceitos da sociedade. $\mathrm{O}$ conselho é de se relacionar com as mulheres só por divertimento, o que Adolfo julga ser imoral. Isto é, enquanto para o seu pai o laço real é o do casamento contraído sem amor e sem paixão, por conveniência, e as demais relações com mulheres são regidas pela busca do prazer, para Adolfo os laços reais são os que se baseiam no amor, o que portanto exclui tanto o matrimônio por conveniência social e financeira (modelo do casamento aristocrático que já não faz parte do ideal burguês) quanto o que seu pai chamava de "divertimentos".

Adolfo representa, enfim, o fracasso de um amor romântico que se propõe eterno encarnado em Eleonora, e a aporia do amor burguês, que não quer dobrar-se diante do amor eterno mas não sabe o que pôr no lugar, refletindo o esvaziamento do coração. 


\section{Considerações Finais}

O objetivo desta dissertação foi mostrar que o liberalismo de Benjamin Constant é uma teoria política construída para salvar as propostas iniciais da Revolução Francesa e oporse às conseqüências práticas geradas depois de 1789: os abusos dos anos do Terror, a ditadura de Napoleão e o possível retorno ao Antigo Regime proposto pelos monarquistas moderados.

Para tanto, vimos no primeiro capítulo, que a liberdade individual dos modernos deve ser preservada e blindada, pois é a forma de proteger o indivíduo das arbitrariedades do poder. Mas, vimos também, que se não houver participação política, tanto a liberdade individual torna-se ameaçada quanto abre espaço para a ditadura ou para o retorno ao Antigo Regime.

No segundo capítulo, vimos que Constant aceita parte da idéia de soberania do povo, mas rejeita justamente o aspecto que ele viu, na prática, degenerar a política em despotismo: é preciso limitar o poder do Estado. Outra forma de garantir esse limite é a participação política do indivíduo, uma forma de controle do poder do Estado. A teoria política de Benjamin Constant busca responder à experiência política que ele vivencia. Assim, acusou Robespierre e Napoleão de tentarem reproduzir em tempos modernos o que fora vivenciado pelos antigos: a liberdade política e o triunfo das guerras. A crítica ao anacronismo faz aparecer um problema de fundo da teoria de Constant. Há uma forte idéia de progresso que faz com que o indivíduo moderno não seja o mesmo que o antigo. Na verdade, mais que a idéia de progresso, há uma idéia de diferença entre as duas épocas. Essa diferença contém, sim, uma noção de progresso, mas se tivermos que distinguir o principal do secundário, diremos que a diferença é o ponto central e o progresso o seu complemento. A marcha da história dos homens construirá a igualdade, mas a liberdade do indivíduo não pode esperar. É um princípio que deve ser preservado independente das ações dos homens, seja da sociedade, seja do Estado. A liberdade individual é da natureza do homem moderno.

No terceiro capítulo, vimos que a necessidade de articulação entre a liberdade individual e a participação política confere um traço peculiar à teoria liberal de Benjamin 
Constant. Vimos também que há uma concepção de indivíduo moderno que se delineia sobretudo pelo confronto com a sociedade e com o Estado.

A sociedade é um estorvo para o indivíduo moderno, tanto na sua relação com a política, como indivíduo civil, quanto na sua vida íntima, como indivíduo moral, como vimos na literatura. Mas a liberdade pensada para o indivíduo na sua esfera civil é criativa, positiva ${ }^{74}$ na medida em que protege sua vida privada para que possa desfrutá-la com tranqüilidade. Já no romance, vimos um indivíduo que conquista a liberdade-independência, sem saber o que fazer com ela; é uma liberdade estéril. Se o problema da liberdade civil é que o indivíduo não tem laços, não se vincula à política (daí Constant chamar a atenção para a necessidade de participação política), no romance o problema é justamente fazer o laço com outro indivíduo. Se Adolfo não sofreria menos se amasse mais, é preciso não fazer ligações, conforme aconselha seu pai.

O homem antigo tinha uma liberdade - essencialmente política - que o tornava pleno, satisfeito e tinha objetivos claros, como a participação na vida política e a glória conquistada pelas guerras. A liberdade moderna, mais do que política, é um fim que está na vida privada, que na modernidade se torna mais rica que a pública. Só que esse objetivo pode causar um esvaziamento no indivíduo, como vimos em Adolfo. Não podemos mais exigir o retorno do modelo antigo de cidadão. Então, perguntamos junto com Constant, para que preservar a identidade moderna, já que o indivíduo é fraco, oscilante, frouxo nas paixões políticas e angustiado, sofredor e perdido na independência da vida íntima? É preciso aceitar esse vazio? Ou, talvez, possamos pensar que Constant, autor inconstante como foi acusado, está na verdade empenhado mais em expor os dilemas, as antinomias do indivíduo cujo crescimento ele presencia, na política, na sociedade, no amor, do que em dar uma única resposta? Se assim for, há uma atualidade de suas indagações que torna mais rico lê-lo como quem formula perguntas do que como quem dá respostas. O caráter de obra aberta, cheia de indagações, do Adolfo se casaria então melhor com a conclusão inquietante d'A liberdade dos modernos do que com a parte inicial, mais afirmativa, dessa conferência. $\mathrm{O}$ que procuramos,

\footnotetext{
${ }^{74}$ É negativa na medida em que se define pela exclusão dos outros, a liberdade é poder fazer o que quiser contanto que não interfira nos direitos dos outros.
} 
aqui, foi não dar tanta ênfase ao Constant enfático, positivo, mas apontar o Constant consciente do que há de negativo, duvidoso, difícil nos tempos que ele vê nascerem. 


\section{Bibliografia:}

ARENDT, Hannah. A condição humana. Trad. Roberto Raposo. Rio de Janeiro: Forense, 2000.

BASTID, Paul. Benjamin Constant et sa doctrine. Paris: Armand Colin, 1966.

CONSTANT, Benjamin. Écrits Politiques. Paris: Gallimard, 1997.

. Principes de Politique. Paris: Hachette, 1997.

Escritos de Política. Trad. Eduardo Brandão, Intr. Celia Quirino. São Paulo: Martins

Fontes, 2005.

. Adolpho. Trad. Carlito Azevedo. Rio de Janeiro: Imago, 1992.

De la Religion. Lausanne: Bibliothèque romande, 1971.

.Liberdade dos Antigos comparada à dos Modernos. Filosofia Política, n 2. 1985.

ELIAS, Norbert. A Sociedade dos Indivíduos. Trad. Vera Ribeiro. Rio de Janeiro: Zahar, 1994.

FLORENZANO, Modesto. Da força sempre atual do pensamento de Benjamin Constant e da necessidade de reconhecê-lo. Artigo in: Revista de História., $\mathrm{n}^{\circ}$ 145, Humanitas, São Paulo, 2001.

GAUCHET, Marcel. La Condition Politique. Paris: Gallimard, 2005. Benjamin Constant: l'illusion lucide du libéralisme. Préface de Constant, Écrits Politiques. Paris: Gallimard, 1997.

HARTOG, François. Da liberdade dos antigos à liberdade dos modernos: o momento da Revolução Francesa. In: O Avesso da Liberdade., Org. Adauto Novaes. São Paulo: Cia das Letras, 2002.

HOFMANN, Etienne. Les Principes de Politique de Benjamin Constant: la genèse d'une euvre et l'évolution de la pensée de leur auteur. Genève: Droz, 1980.

HOLMES, Stephen. Benjamin Constant et la genèse du libéralisme moderne. Trad. Olivier Champeau. Paris: Presses Universitaires de Frances, 1994. 
LEFORT, Claude. Pensando o Político. Trad. Eliana M. Souza. Rio de Janeiro: Paz e Terra, 1991.

LÉON, Paul. Benjamin Constant. Paris: Rieder, 1930.

LOSURDO, Domenico. Hegel, Marx e a tradição liberal. Trad. Carlos Alberto Dastoli. São Paulo: Unesp, 1998.

MANENT, Pierre. História intelectual do liberalismo - dez lições. Trad. Vera Ribeiro. Rio de Janeiro: Imago, 1990.

RIBEIRO, Renato Janine. A Democracia. São Paulo: Publifolha, 2001.

STAËL, Mme. de. Des circonstances actuelles qui peuvent terminer la Révolution et des príncipes qui doivent fonder la republique em France. Genène: Droz, 1979.

TODOROV, Tzvetan. Benjamin Constant: la passion démocratique. Paris: Hachette, 1997. 